\title{
Foreign investor reactions to risk and uncertainty in antitrust: U.S. merger policy investigations and the deterrence of foreign acquirer presence
}

\author{
Joseph A. Clougherty ${ }^{1}$ and \\ Nan Zhang ${ }^{2}$
}

\footnotetext{
${ }^{1}$ Gies College of Business, University of Illinois at Urbana-Champaign, 330 Wohlers Hall, 1206 S. 6th St., MC-706, Champaign, IL 61820, USA;

${ }^{2}$ College of Business Administration, California State University Stanislaus, 223 Demergasso-Bava Hall \#21, One University Circle, Turlock, CA 95382, USA

\section{Correspondence:}

JA Clougherty, Gies College of Business, University of Illinois at Urbana-Champaign, 330 Wohlers Hall, 1206 S. 6th St., MC-706, Champaign, IL 61820, USA

e-mail: jaclough@illinois.edu
}

Journal of International Business Studies (2021) 52, 454-478.

https://doi.org/10.1057/s4| 267-020-00338-6

Keywords: cross-border mergers and acquisitions; policy-oriented studies; MNE-hostcountry relationships; business/government interaction and relationships

The online version of this article is available Open Access

\section{INTRODUCTION}

Does the enforcement of competition policy - antitrust policy in U.S. parlance - negatively affect inward foreign investment activities? While the presence of national competition policies in the cross-national environment for global business has been largely attributed to the need to secure the welfare benefits from effective domestic competition (e.g., Buccirossi, Ciari, Duso, Spagnolo, \& Vitale, 2013; Porter, 1998), Graham and Warner observe that "a consistent complaint of international business executives directed toward competition authorities is that major decisions involve somewhat parochial considerations ... [which in turn] ... inhibit

\begin{abstract}
Motivated by the potential for antitrust and competition policies to be
Abstract protectionist in effect, we formulate the theoretical prior that merger policy deters foreign acquirer participation in local M\&A markets. The policy risk and policy uncertainty characteristic of merger review may negatively affect foreign acquirers more so than domestic acquirers, thereby disadvantaging foreign acquisitions of local firms and deterring future cross-border investment activities. We test this prior by employing sector-level data on U.S. merger policy investigations and foreign acquirer presence in U.S. M\&A markets over the 2002-2017 period. Our panel-data methodological approach indicates that the risk and uncertainty characteristic of U.S. merger policy disproportionately deters the acquisition activities of foreign investors. The empirical results also suggest that the application of competition and merger policies in other national jurisdictions - where there is less of a strong commitment to antitrust principles - might also be effectively protectionist.
\end{abstract}

Electronic supplementary material The online version of this article (https://doi.org/10.1057/s41267-020-003386) contains supplementary material, which is available to authorized users.

Received: 24 September 2018

Revised: 19 April 2020

Accepted: 5 May 2020

Online publication date: 12 June 2020 
international mergers, acquisitions and investments" (1994: 469). Due to the potential presence of both positive and negative mechanisms connecting competition policy with inward FDI activities, Brewer (1993) long ago called for international business researchers to engage in systematic study of the relationship between competition policy and FDI. This call for research has been echoed by a number of influential IB scholars (e.g., Buckley \& Casson, 1996; Hennart \& Reddy, 1997; Peng, Sun, Pinkham, \& Chen, 2009; Rugman \& Verbeke, 2001) who also saw merit in our literature gaining a better understanding of how competition policy affects foreign investment activities. Despite these calls for research, IB scholarship has yet to engage in empirical work that considers the relationship between competition policy and foreign investment activities.

There exists, however, both theoretical and empirical scholarship in the related fields of international trade, law and economics, and finance economics; yet, Evenett (2003) observes that the literature in these fields has presented mixed findings. For instance, a number of scholars (e.g., Bris, Brisley, \& Cabolis, 2008; Bris, Cabolis, \& Janowski, 2007; Clarke, 2003; Oliveira, Hochstetler, \& Kalil, 2001) have found the enforcement of competition policy to encourage inward FDI activity. Those who find support for a positive relationship often focus on the premise that well-run competition policy establishes a level playing field for all competitors where such fairness in treating foreign and domestic firms alike (Grosse \& Trevino, 2005) is particularly advantageous for foreign investors who generally suffer from a liability of foreignness (Zaheer, 1995). Yet other scholars have considered the enforcement of competition policy to be best characterized as protectionist in nature (e.g., Aktas, Bodt, \& Roll, 2007; Conybeare \& Kim, 2010; Deshpande, Svetina, \& Zhu, 2016; Dinc \& Erel, 2013; Evenett, 2002; Francois \& Horn, 2007; Hemphill, 2010; Li, 2007). The prior in this literature stream is that governments prefer domesticallyowned entities; hence, authorities conduct competition policy - especially the sub-policy of merger control - in a manner so as to deter foreign ownership and encourage domestic ownership of local businesses. Foreign firms are accordingly subjected to regulatory requirements that ensure that investments support, rather than compete with, domestic business (Brooks, 2007). While such requirements reflect the interests of national governments in protecting local business (Caporaso \&
Levine, 1992), the use of competition policies in such a manner would ultimately lead to diminished inward FDI.

The methodological practices generally employed by the pre-existing empirical literature potentially contribute to these mixed empirical findings, as such practices can yield biased results. Specifically, the empirical literature exhibits a proclivity to engage in cross-country empirical studies (e.g., Bris et al., 2007; Clarke, 2003) that do not comprehensively account for potentially confounding factors. Yet, establishing sound causal inferences regarding the relationship between competition policy and inward FDI is fraught with identification challenges in empirical contexts, where omitted country-level factors likely correlate with both the implementation of competition policy and the openness of a country toward FDI. For instance, the pro-market tendencies characteristic of the U.S. - observed by Peng, Wang and Jiang (2008) and others - represents a potential omitted construct that will tend to enhance both competition policy and inward FDI activity, thereby adding observations to a naïve cross-country OLS estimation that would bias the coefficient estimates toward a positive relationship (Bascle, 2008; Wooldridge, 2013).

With the above methodological deficiencies in the pre-existing literature in mind, we attempt to bring some definitive empirical evidence to bear in order to establish whether competition policy might negatively affect inward FDI activity levels. We first narrow the focus of study by considering the impact of U.S. merger policy enforcement on the proclivity of foreign acquirers to participate in the U.S. markets for corporate control. While competition policy involves three elements (merger review, price collusion, and abuse of dominance), merger policy represents the most important element of a national commitment to antitrust principles (Viscusi, Vernon, \& Harrington, 1995), and the most salient element of competition policy concerning foreign investors. ${ }^{1}$ Second, we move beyond a cross-country methodological approach by employing sector-level data on U.S. merger policy investigations and sector-level data on the acquisition activities undertaken by foreign and domestic firms. The sector-level empirical approach mitigates the concern with respect to omitted country-level factors being responsible for a spurious causal relationship between competition policy and inward FDI. 
In addition to the empirical features of our analysis, we ground our conceptual development within the IB literature, focusing on the relevance of political risk and uncertainty in foreign investment decisions (e.g., Delios \& Henisz, 2000, 2003a, b; Kobrin, 1979; Kobrin, Basek, Blank, \& La Palombara, 1980). Thus, in focusing on the application of U.S. merger policy and how that policy might negatively impact foreign acquirers as compared to domestic acquirers, we consider the ability of merger control to manifest both policy risk and policy uncertainty. By policy risk, we refer to situations where the possibilities and probabilities of policy outcomes are known to market participants in the sense that they can be forecast (Knight, 1921; Kobrin, 1979); and by policy uncertainty, we refer to situations where the possibilities and probabilities of policy outcomes are not well known to market participants, in the sense that it is difficult to forecast the likelihood of future policy states (Bloom, 2014; Knight, 1921; Kobrin, 1979). Moreover, our theoretical priors consider how merger policy enforcement involves both policy risk and policy uncertainty elements, where increases in these factors would lead to foreign acquirers being disproportionately deterred from engaging in acquisitions as compared to domestic acquirers.

After setting our theoretical priors, we empirically test our two hypotheses on sector-level data covering 53 U.S. industries over the 2002-2017 period. Our panel-data empirical results indicate that merger policy investigative activities disproportionately deter foreign acquirers in local M\&A markets. Specifically, increases in merger policy risk and merger policy uncertainty lead to reduced foreign acquirer presence in the U.S. markets for corporate control. The empirical evidence then suggests that merger policy enforcement is protectionist in effect, as foreign investment activities are more adversely affected by the application of merger policy as compared to domestic investment activities. These results yield salient implications for the international business literature on hostcountry characteristics and foreign investment activities.

In order to comprehensively examine the relationship between merger policy enforcement and foreign acquirer presence in local M\&A markets, we structure the remainder of this paper as follows. We present a theoretical framework that focuses on the salience of policy risk and policy uncertainty in generating two hypotheses regarding the relationship between the enforcement of merger policy and the participation of foreign acquirers in domestic M\&A markets. After setting out our theoretical priors, we describe our sector-level data on U.S. merger control and acquisition activities, formulate our estimation strategy, present our empirical results, and discuss robustness testing. The last section concludes.

\section{HYPOTHESES DEVELOPMENT}

A considerable amount of IB literature has examined the impact of country-level political risk and uncertainty on inward FDI activities - see the literature reviews by Kobrin (1979), Fitzpatrick (1983) and Liesch, Welch, and Buckley (2011). The basis behind this literature is that political risks and uncertainties can "arise from the actions of national governments which interfere with or prevent business transactions" (Weston \& Sorge, 1972: 60). Firms generally react to such political hurdles by reducing their willingness to make investments as the option value of delaying investment becomes higher under such risks and uncertainties (Bloom, 2014; Brouthers, Brouthers, \& Werner, 2008). While political hurdles and hazards can negatively influence the investment activities of all firms, foreign firms are generally considered to be more sensitive to such shocks. For one, foreign firms might be more frequently targeted when burdensome laws, regulations and policies are implemented by national governments; e.g., Eden (1994) observes that national policies practiced in a parochial manner represent fundamental threats to multinationals. Furthermore, foreign firms often lack the local information, legitimacy and contacts which might help them properly assess and mitigate political constraints. As Werner, Brouthers, and Brouthers (1996: 572) underscore, "firms commonly find international business opportunities to be inherently more risky than domestic ones" due to the stark differences in political environments and the inherent legal uncertainties characteristic of foreign investment endeavors. It is no surprise then that a great deal of empirical literature (e.g., Delios \& Henisz, 2000, 2003b; Henisz \& Delios, 2001) indicates that uncertainty in the political environment substantially deters foreign investment activities. Indeed, Kobrin (1979) highlights how the response to political risk and uncertainty is frequently avoidance, as multinationals simply do not get involved in countries perceived as risky. 
While macro-level studies regarding the relationship between political risk and FDI tend to dominate the literature (Vadlamannati, 2012), there have been efforts to follow the prescriptions of Kobrin (1979) to consider the industry-, firm-, and project-specific factors relating to political risk and uncertainty. For one, Miller (1993) breaks down the salient host-country environmental uncertainties into six different dimensions - where uncertainties with respect to specific government policies represent the first dimension. Werner et al. (1996) follow in this line of research by considering the national laws which affect foreign firms; and Grosse (1985) and Bonaime, Gulen, and Ion (2018), respectively, consider the impact of regulatory policies and uncertainties on FDI and M\&A activities. The conduct of national merger policy represents a particular regulatory policy that involves a direct threat to the participation of foreign firms in local M\&A markets. Specifically, the presence of a national merger policy can negatively impact foreign acquirers by slowing down the consummation of their cross-border acquisitions via antitrust investigations, curtailing the profitability of these cross-border acquisitions by requiring structural remedies, and by even outright prohibiting them. Thus, merger control is a specific and salient government barrier that foreign acquirers must successfully navigate in order to gain access to local M\&A markets (Brouthers et al., 2008; Clougherty, 2005).

While the IB literature lacks empirical scholarship concerning this topic, many IB scholars (e.g., Brewer, 1993; Buckley \& Casson, 1996; Hymer, 1970; Spar, 2001) have posited that the national enforcement of merger policy potentially restrains the level of inward FDI. It is with these concerns in mind that many policy advisors recommend that countries do not prioritize competition policy, as it could discourage inward FDI via the creation of additional regulatory barriers and uncertainties for foreign investors (Oliveira et al., 2001). Moreover, the conduct of national merger policy lends itself well to analyzing the deterrence effects with respect to acquisition activities in a manner that is consistent with the pre-existing literature on political risk and uncertainty. First, merger policy is conducted at the industry level and exhibits cross-sector variation in antitrust scrutiny (Clougherty \& Seldeslachts, 2013); thus, it represents an industryspecific policy context worth analyzing for policy risk factors in line with Kobrin's (1979) prescriptions. Second, merger policy involves both policy risk and policy uncertainty - both of which may disproportionately deter foreign acquirers as compared to domestic acquirers. We turn now to a discussion of these concepts and to the formulation of our theoretical priors.

\section{Merger Policy Risk}

The concept of risk goes back to Knight's (1921) fundamental insights, where he considered risk to be a known probability distribution over a set of events; for example, flipping a coin involves risk, but with known odds. In moving from the concept of risk to its application in IB political risk, Kobrin (1979) observes that risk is at play when managers have knowledge regarding the possibility and probability of different political outcomes via either calculations or past experience statistics. While the relevant information is available with political risk, and observers generally agree with respect to the probabilities of different outcomes, foreign investors are often considered to be at a disadvantage as compared to domestic investors due in part to inherent information asymmetries (Gehrig, 1993; Gordon \& Bovenberg, 1996; Liesch et al., 2011). As Gehrig (1993: 98) makes clear, "information may have to be interpreted in the light of the legal conventions and business culture of a particular community, which may be difficult for foreigners to assess". Thus, domestic investors are better informed and better able to interpret the relevant probabilities as compared to foreign investors, and, as a result, foreign managers tend to overestimate the risks and underestimate the benefits involved with host-country investment activities (Liesch et al., 2011). Simply put, the lack of information, knowledge, and experience with respect to the intricacies of host-country activities accentuates the perceptions of risk when considering foreign investments. A great deal of the political risk literature accordingly focuses on the probabilistic estimates of different policy outcomes and how increased risk leads to decreased foreign investment activities. With the above as a backdrop, we consider how the policy risk involved with merger control might disproportionately affect foreign investors considering participating in the local markets for corporate control.

First, the presence of a host-country merger policy involves transaction costs that foreign investors must factor when deciding upon whether - and to what extent - to make a cross-border acquisition. Navigating the host-nation's merger review process also involves several direct costs - 
e.g., legal, transaction filing, and advisory services fees - in order to clear the transaction (Hemphill, 2010). In addition, acquiring firms face internal organizational costs that require in-house legal expertise as well as managerial time and commitment due to the presence of host-nation merger policies. Importantly, the direct costs and transaction costs involved with the merger review process are particularly salient for foreign acquirers as compared to domestic acquirers. For one, foreign investors will be generally unfamiliar with the institutions, values, norms, and networks that are embedded within the host-nation's antitrust institutional environment (Jorde \& Teece, 1990). For example, General Electric exhibited unfamiliarity with European Commission (EC) regulatory procedures in offering concessions to EC officials for the proposed Honeywell acquisition that would have been more appropriate in the U.S. institutional context (Desai, Villalonga, \& Veblen, 2005; The Economist, 2001). As such, acquiring firms often enter negotiations with antitrust officials in order to come to a negotiated settlement with respect to the conditions and remedial actions necessary for successful resolution of antitrust concerns (Farrell, 2003). Yet, as Grosse and Behrman (1992) highlight, multinational firms are at a distinct bargaining disadvantage when the host-country institutions are strong and when the multinational lacks salient information about the institutional environment. As a result, the policy risk involved with greater degrees of merger policy enforcement will lead to disproportionate deterrence of foreign acquirer activities as compared to domestic acquirer activities, due to foreign acquirers being more likely to incur costly and inappropriate regulatory efforts that do not ultimately deliver successful antitrust approval.

Second, foreign acquirers will tend to be more risk averse as compared to domestic acquirers when factoring the costs involved with greater degrees of merger policy risk. As George, Chattopadhyay, Sitkin, and Barden (2006) point out, risky behavior is more likely when managers perceive a sense of mastery or control over a particular domain; thus, higher degrees of merger policy risk will not be experienced by foreign investors with the same sense of control over the review process as experienced by domestic investors. In fact, Kobrin (1979) highlights that perceptions of risk are a function of the available information and previous experiences - qualities which are both less likely to characterize foreign acquirers as compared to domestic acquirers. Liesch et al. (2011: 856) summarize the above well when they state "many firms have been found to be lacking in information and knowledge about, and experience in ... the practicalities of international activity" thereby accentuating perceptions of political risk. As a result, the policy risk involved with greater degrees of merger policy enforcement will lead to disproportionate deterrence of foreign acquirer activities as compared to domestic acquirer activities due to the inherent differences in risk tolerance exhibited by foreign and domestic investors.

Third, the application of merger policy might disproportionately target the acquisitions undertaken by foreign investors as compared to the acquisitions undertaken by domestic investors. Vadlamannati (2012: 115) outlines how a substantial amount of political risk derives from the fact that governments often "buckle under lobbying pressure from local firms seeking preferential treatment vis-à-vis the foreign firms". Antitrust agencies are ostensibly independent from political influence; yet, in very few instances are such institutions fully independent of politics. In fact, a number of scholars (e.g., Coate, Higgins, \& McChesney, 1990; Faith, Leavens, \& Tollison, 1982; Mehta, Srinivasan, \& Zhao, 2020; Neven, Papandropoulos, \& Seabright, 1998) consider antitrust outcomes to be - at least partially - subject to political pressure. Yet, foreign firms suffer from a liability of foreignness when attempting to influence national authorities, as they are simply less capable and legitimate as compared to domestic firms in terms of employing the political economic mechanisms that yield privileges via corporate political strategy (Boddewyn, 1988; Grosse, 2005; Hymer, 1976 [1960]; Kindleberger, 1969; Zaheer, 1995). Accordingly, antitrust authorities face political pressure to provide some leniency that favors domestic investors (Rodriguez \& Menon, 2010). In line with these priors, the Chinese (Horton, 2016; Zhang \& Zhang, 2010) and EC antitrust authorities (Aktas et al., 2007; Dinc \& Erel, 2013) have been reported to protect indigenous firms by treating domestic acquisitions more leniently than foreign acquisitions. As a result, the policy risk involved with greater degrees of merger policy enforcement will lead to disproportionate deterrence of foreign acquirer as compared to domestic acquirer activities due to foreign acquirers receiving greater antitrust scrutiny.

Summarizing the above, merger policy risk likely involves a larger deterrence effect with respect to 
foreign acquirer activities as compared to domestic acquirer activities in local M\&A markets due to the presence of three mechanisms. First, merger policy involves costs that acquiring firms must incur while navigating the merger review process, and foreign investors disproportionately experience these costs due to their inherent liabilities and information asymmetries. Second, foreign investors tend to be more risk averse as compared to domestic investors which in turn generates more cautious investment behavior. Third, antitrust agencies potentially scrutinize the acquisition activities undertaken by foreign investors more than the acquisition activities undertaken by domestic investors. These three mechanisms negatively impact foreign acquisitions of indigenous firms and deter future foreign investors who refrain from cross-border acquisitions due to the presence of these realities (Dinc \& Erel, 2013). Based on the above reasoning, our first theoretical prior can be formulated as follows:

Hypothesis 1: Increases in merger policy risk will negatively affect the relative presence of foreign acquirers in local M\&A markets.

\section{Merger Policy Uncertainty}

While the concept of uncertainty has been considered to be somewhat amorphous in the extant literature, there is general consensus that it reflects a degree of doubt about possible future states (Bloom, 2014). In conceptualizing uncertainty, Knight (1921) focused on the inability to forecast the likelihood of future events, as agents have no idea how to commence engaging in such calculations. For example, flipping a coin and rolling a die come with different - but known - odds (i.e., different risks), yet, if an actor was not provided information on whether a die or coin was thrown, then they would have uncertainty with respect to forecasting odds. Penrose (1972: 56) also differentiates the concept of uncertainty from the related concept of risk by holding that risk refers to estimates of possible outcomes, while uncertainty refers to confidence in these estimates. Similarly, Williamson's (1985) uncertainty invokes situations of ambiguity and sketchiness in combination with the bounded rationality of humans which hinders factoring all possible outcomes. Businesses are accordingly unsure as to all of the possible outcomes and unsure as to the applicable probabilities of these outcomes under uncertainty. Bloom (2014: 165) notes that, in such conditions, "agents are so uncertain about the future they cannot form a probability distribution. Instead, they have a range of possible outcomes and act as if the worst outcomes will occur, displaying a behavior known as ambiguity aversion". Kobrin (1979) highlights how uncertainty is very much subjective in nature due to the manager's inability to appropriately shape the relevant probability distribution.

In moving from the concept of uncertainty to its application in political uncertainty, it should be underscored that it arises because governments can undertake policies and actions that both aid and hinder business operations. Indeed, a number of scholars have established that a substantial degree of public policy volatility manifests in the U.S. and in the cross-national environment for business (e.g., Baker, Bloom, \& Davis, 2016; Henisz, 2004). While national policies affecting business vary for a number of reasons (e.g., Baker et al. 2016 find experimentation with policies during recessions), investors must factor the uncertainties involved with the potential realization of different policy outcomes. For instance, Bloom (2014) observes that public policies that are unclear and volatile in nature will raise uncertainty on the part of market participants. Moreover, the existence of political uncertainties and instabilities increases the costs of long-term capital investments that lead to growth (Grosse \& Trevino, 2005; Henisz, 2000); thus, the willingness of firms to make investments decreases when uncertainty with respect to policy outcomes increases. In essence, businesses are simply unlikely to proceed with substantial investments unless policy uncertainties are reduced to acceptable levels. Liesch et al. (2011: 863) summarize these ideas in the cross-border business context well when stating that "volatile foreign environments, with rapid change and disruption, intrusive government action, tend to be seen as heightening uncertainty and ... in a negative way, discouraging involvement".

Closer to the context of our analysis, the application of national merger policies can involve substantial sector-level policy uncertainty. Indeed, the consummation of both domestic and crossborder acquisitions requires that transactions successfully pass through a merger review process. The U.S. established the first pre-notification merger review process with the Hart-Scott-Rodino (HSR) Act of 1976, and in subsequent years such procedures have proliferated to over 70 antitrust jurisdictions throughout the world (Galloway, 2009; Motta, 2004). While there exists a substantial degree of cross-national heterogeneity with respect 
to the laws, procedures, and applications of merger policy (Clougherty, 2001, 2005), there also exists a substantial degree of volatility in merger policy application within nations and within sectors. For instance, a great deal of scholarship has considered the causes behind temporal swings in the tenor and scope of U.S. antitrust enforcement (e.g., Moe, 1987; Vachris, 1996; Weingast \& Moran, 1983). In addition to time variation, scholars have also found substantial variation across industries in the application of merger policy (Clougherty, Duso, Lee, \& Seldeslachts, 2016; Clougherty \& Seldeslachts, 2013). This cross-sector variation in the strictness of merger control has been considered to be driven by antitrust staffing constraints which limit scrutinizing all industries (Kwoka, 1999), the presence of both 'shutdown' and 'safe haven' sectors where firms understand horizontal activities will be respectively scrutinized at high and low levels (Deloitte \& Touche, 2007), and variability in the ability of domestic industry participants to lobby for accommodating policies (Mehta et al., 2020).

While the application of merger control exhibits volatility across industries and time which leads to the relevant policy uncertainty, it is important to highlight how policy uncertainty tends to disproportionately affect foreign investors as compared to domestic investors. Gordon and Bovenberg (1996) point out that it is the existence of information asymmetries - where foreign investors exhibit a particular handicap as compared to domestic investors - which explains the fact that foreign investors tend to be robustly deterred by hostnation uncertainties. As they make clear, domestic investors will generally have better access to information and be better able to predict future government policies which affect firm profitability. In line with these priors, Grosse and Trevino (2005) highlight how an opaque and uncertain regulatory environment represents a substantial cost for foreign firms operating in a host country. Indeed, Kobrin (1979) notes that policy uncertainty is quite likely in cross-border business transactions, as managers are uncertain with respect to the different policy outcomes and the probabilities associated with these outcomes. For instance, GE's acquisition of Honeywell was unexpectedly prevented by the enforcement of EC competition policy and not by the enforcement of U.S. antitrust policy (The Economist, 2001). Foreign investors face a distortion due to subjective factors that simply cannot be eliminated; thus, foreign investors commonly respond to greater host-country policy uncertainty by avoiding investments like cross-border acquisitions which entail high commitments (Liesch et al., 2011).

Summarizing the above, merger policy uncertainty likely involves a larger deterrence effect with respect to foreign acquirer as compared to domestic acquirer activities in local M\&A markets due to the presence of substantial information asymmetries. While uncertainties with respect to the strength and tenor of sector-level merger policy will impact both domestic and foreign acquirers, the acquirers hailing from foreign countries face particular disadvantages with respect to properly assessing these uncertainties regarding the future states of merger policy. Thus, higher degrees of uncertainty regarding the merger review process will negatively impact foreign acquisitions of indigenous firms and deter future foreign investors who refrain from cross-border acquisitions due to the presence of these uncertainties. Based on the above reasoning, our second theoretical prior can be formulated as follows:

Hypothesis 2: Increases in merger policy uncertainty will negatively affect the relative presence of foreign acquirers in local M\&A markets.

\section{METHODOLOGY}

\section{Dataset and Variable Description}

We assembled data covering 53 industrial sectors over the 2002-2017 period in which each panel consists of an industrial sector at the three-digit level, conforming to the North American Industry Classification System standard. For instance, "chemical products" represents one distinct panel consisting of 15 years of annual data. Due to both missing values and employing lagged variable structures, our unbalanced panel dataset consists of 563 industry-year observations for empirical estimations. In order to compile our dataset, we matched observations from six separate sources: the 'SDC Platinum' data from Thomson; the 2002 through 2017 'Annual Reports to Congress on HSR Antitrust Enforcement' from the U.S. Federal Trade Commission (FTC) and the U.S. Department of Justice (DOJ); the 'Annual Reports to Congress from the Committee on Foreign Investment in the United States' from the U.S. Department of the Treasury; the 'Gross Domestic Product (GDP) by Industry' dataset from the U.S. Bureau of Economic 
Analysis (BEA); the 'Compustat' database from Wharton Research Data Services; and the 2017 YouGov poll on 'America's Friends and Enemies'. The six data sources were respectively compiled and harmonized in order to yield consistent measures for the three principal variables - Foreign-AcquirerPresence, Merger-Policy-Risk, and Merger-PolicyUncertainty - required to test our theoretical priors, as well as a full set of control variables. The appendix reports sector-level descriptive statistics for each of the 53 three-digit sectors: the number of observations included in the estimation sample, and means for the three principal variables. ${ }^{2}$ As an aside, please note how foreign investors are involved on average in $27 \%$ of the acquisitions taking place in the U.S. sectoral markets for corporate control, and that 45 sectors involve a foreign acquirer presence above the 10\% level.

Thomson's SDC Platinum database provides transaction-level data that allow differentiating between foreign and domestic acquisitions of U.S.-based targets to compile an industry-based measure of foreign acquirer presence in the local markets for horizontal M\&A activities. The Thomson database is the most reputable source of transaction data and involves extensive coverage of both domestic and cross-border acquisition activities. Furthermore, our sample consists of all those horizontal transactions where the acquiring firm gained full, majority, or minority control of the target firm. We focus on horizontal transactions, as U.S. antitrust authorities have long considered horizontal transactions to represent the population of anti-competitive transactions, whereas non-horizontal - i.e., vertical and conglomerate - transactions are rarely considered to involve anti-competitive effects (Viscusi et al., 1995). ${ }^{3}$ Specifically, horizontal transactions are defined as involving four-digit overlap in the product space of the acquiring and target firms; thus, our definition of a horizontal transaction is tighter than the three-digit-level observational units. We compiled all of the transaction-level data on acquisition values into an industry-based annual measure for the value of foreign acquisitions of U.S. targets, and an industry-based annual measure for the value of domestic acquisitions of U.S. targets. Foreign acquirer participation in these local M\&A markets was then captured by taking the value of foreign acquisitions and dividing by the value of total acquisitions (both foreign and domestic) in the local M\&A markets. Accordingly, our dependent variable, Foreign-Acquirer-Presence, is a percentage, and represents the degree to which foreign acquirers participate in the U.S. sectoral markets for corporate control.

The "Annual Reports to Congress on HSR Antitrust Enforcement" provide data on the annual number of 'second-request-investigations' that the DOJ and FTC undertake in a specific three-digit sector. The HSR merger review process requires merging firms to report their transactions to U.S. antitrust officials for approval prior to consummating these transactions. While the majority of merger notifications are cleared by authorities within 30 business days, a number of transactions receive a 'second-request-investigation' (Kovacic, 2003). These investigations require merging firms to divulge additional information and documents to antitrust authorities, and mandate an additional waiting period for the consummation of the transaction. The fact that investigations require the revelation of what might be sensitive information and prolong the time to complete the intended strategy indicates that these investigations represent a substantial source of holdup to managers (Clougherty, 2005). Investigations also represent a prerequisite step for antitrust officials to engage in more serious antitrust measures such as structural divestments and outright preventions. As Deshpande et al. (2016) point out, the presence of an investigation increases the policy risk as to whether and when the transaction can be legally achieved, thereby decreasing the expectation that gains can be reaped, and in turn decreasing stock market valuations.

These sectoral-level data on antitrust investigations form the basis for creating our measures of merger policy risk and merger policy uncertainty. First, we follow Kobrin's (1979) insight with respect to policy risk being characterized by investors having knowledge concerning the probabilities of certain outcomes based on past experiences. Thus, we can employ an antitrust investigation rate - the number of annual second-request-investigations in a sector divided by the number of horizontal transactions in the sector - in order to capture the probability that a horizontal acquisition receives an investigation by U.S. antitrust authorities. This investigation rate conforms to the 'rates of detection' measures employed in the deterrence literature following the work of Becker (1968) and Ehrlich (1973). Accordingly, our first main explanatory variable, Merger-Policy-Risk, captures the probabilistic risk of incurring antitrust scrutiny faced by 
investors interested in participating in the U.S. markets for corporate control.

Second, we follow Penrose's (1972) observation that it is confidence in the assessments of the future which defines uncertainty, as Knight's (1921) uncertainty involves an inability to forecast future states. While forecaster disagreement, mentions of uncertainty, and options markets for stocks have all been employed as measures of uncertainty, Bloom (2014) observes that the volatility of past measures - as captured by a standard deviation - has been the most frequently employed uncertainty measure (e.g., Baillie \& DeGennaro, 1990; Bessembinder \& Seguin, 1992; French, Schwert, \& Stambaugh, 1987). Indeed, greater degrees of dispersion in the previous 'states' for merger policy in an industry indicate that the status of future merger policy is more difficult to forecast and predict. We employ then the standard deviation in the annual number of second-request-investigations in the preceding years as a proxy that reflects the policy uncertainty with respect to the possible future states of merger control in a particular sector. Accordingly, our second main explanatory variable, Merger-PolicyUncertainty, captures the policy uncertainty with respect to the future nature of merger control in a sector faced by investors interested in participating in the U.S. markets for corporate control.

We also require a series of control variables in order to make stronger causal inferences regarding our hypothesized relationships. We first control for the U.S. enforcement of foreign investment review policy, as foreign acquirers will not only need to gain merger review approval but will also need to navigate the Committee on Foreign Investment in the United States (CFIUS) process (Baltz, 2017). Due to its national security mission and exemption from 'Freedom of Information Act' requests, CFIUS - unlike the U.S. DOJ and FTC - does not report details on transaction notifications and investigations at the sectoral level, but instead simply reports data that allow the calculation of an annual pan-industry investigation rate: the number of investigations over the number of transaction notifications. We are, however, able to define which sectors were considered to be of national security importance; thus, we apply this economywide investigation rate to only those sectors scrutinized by CFIUS. Accordingly, our first control variable, CFIUS-Investigation-Rate, captures the degree to which CFIUS takes an active interest in foreign acquisition activities. The expectation is that the application of CFIUS investigations will negatively affect foreign acquirer presence in the U.S. local markets for corporate control.

A great deal of IB literature (e.g., Delios \& Henisz, 2000; Liesch et al., 2011; Rivoli \& Salorio, 1996) holds that experience matters in cross-border investment activities. Indeed, our theoretical priors are based on foreign acquirers being characterized by liabilities, deficiencies, and information asymmetries as compared to domestic acquirers. That said, given an amount of experience by foreign acquirers in a particular host-country with respect to the merger review process, these foreign acquirers will become if not native - at least better - in their ability to navigate the merger review process. We accordingly control for foreign acquirer experience in the United States by including a measure that captures the percentage of foreign acquirers with a previous U.S. acquisition experience in the five preceding years (hereafter referred to as Foreign-Acquirer-Experience). The expectation is that foreign acquirer experience will positively affect foreign acquirer presence in the U.S. local markets for corporate control.

The antitrust deterrence literature (e.g., Clougherty \& Seldeslachts, 2013; Deloitte \& Touche, 2007; Seldeslachts et al., 2009) finds that merger policy enforcement negatively affects domestic M\&A activity, as antitrust also represents an impediment to domestic investors even if such deterrence effects are more substantial for foreign investors. Accordingly - and analogous to the concept of foreign acquirer experience - the experience exhibited by the domestic acquirers active in a particular industry might also affect foreign acquirer presence in a particular industry. Yet the prior here would be that domestic acquirer experience negatively affects foreign acquirer presence in U.S. sectoral M\&A markets, as a higher degree of experienced domestic investor activity would seemingly crowd out the ability of foreign investors to take part in these local M\&A markets. We accordingly control for domestic acquirer experience by including a measure that captures the percentage of domestic acquirers with a previous U.S. acquisition experience in the five preceding years (hereafter referred to as DomesticAcquirer-Experience). The expectation is that domestic acquirer experience will negatively affect foreign acquirer presence in the U.S. local markets for corporate control.

The characteristics of foreign investors might also influence the degree to which foreign acquirers are present in the U.S. sectoral markets for corporate control. First, the degree to which a sector is 
characterized by foreign investment from nations viewed as 'unfriendly' by U.S. residents would suggest that the sector is less important in terms of national security. Furthermore, unfriendly-nation foreign investors involve an increased demand effect, as this would increase the potential set of foreign investors interested in acquiring U.S. firms. As such, both of these mechanisms would indicate a higher foreign acquirer presence in sectors experiencing higher degrees of interest by unfriendlynation investors. We accordingly control for the degree to which unfriendly nations participate in the foreign acquisition activities taking place in a sector (hereafter referred to as Unfriendly-AcquirerParticipation). In addition to unfriendly acquirer participation in U.S. M\&A markets, emerging market firms have increasingly participated in crossborder investment activities over the last 20 years. The participation of these firms in local M\&A markets would also seemingly involve an increased demand effect, as these investors increase the set of foreign investors interested in acquiring U.S. firms. We accordingly control for the degree to which emerging market firms participate in the foreign acquisition activities taking place in a sector (hereafter referred to as Emerging-Acquirer-Participation). The expectation is that both of these controls - Emerging-Acquirer-Participation and Unfriendly-Acquirer-Participation - positively affect foreign acquirer presence in the U.S. local markets for corporate control.

A number of scholars (e.g., Grosse \& Trevino, 2005; Vadlamannati, 2012) have pointed out that larger markets tend to attract greater foreign investment activities. While the pre-existing empirical literature often considers market size to be a determinant of cross-border investment activities in country-level FDI analysis, these concepts regarding the importance of scale are transferable to sectoral markets. Accordingly, we also control for the size of an industrial sector by employing U.S. BEA's data on the economic activity taking place in a sector as captured by the production of new goods and services, less intermediate inputs (hereafter referred to as Industry-Value-Added). The expectation is that Industry-Value-Added will positively affect foreign acquirer presence in the U.S. local markets for corporate control.

There are also priors in the literature with respect to foreign investors being particularly interested in U.S. sectors that exhibit high levels of R\&D and high degrees of college workers, as foreign investors often seek learning opportunities in these particular sectors (Hitt, $\mathrm{Li}, \& \mathrm{Xu}, 2016$ ). We accordingly control for R\&D intensity by employing a measure of $R \& D$ expenditures with respect to the value added for the industrial sector (hereafter referred to as Industry R\&D). Furthermore, we control for the degree to which a sector intensively uses skilled labor by employing a measure of the expenditures on college workers with respect to expenditures on all workers (hereafter referred to as Industry-Skilled-Labor). While these two control constructs involve overlapping priors with respect to the motivations of foreign investors, we include three additional controls (profit rate, tax rate, and the Herfindahl-Hirschman Index) that do not involve priors from the pre-existing literature with respect to foreign acquirer presence, though their inclusion strengthens the model specification and allows for stronger causal inferences. First, we control for the degree to which a sector is characterized by profitability by taking the gross operating surplus (i.e., gross output less the cost of intermediate goods, services, and employees) and dividing by the value added in the sector (hereafter referred to as Industry-Profit-Rate). Second, we control for the degree to which a sector is characterized by a high tax burden by measuring the taxes on production and imports, less subsidies, and then dividing by the value added in the sector (hereafter referred to as Industry-Tax-Rate). Third, we control for the market concentration by employing the Compustat data to calculate the Herfindahl-Hirschman Index (hereafter referred to as Industry-HHI).

Table 1 provides information on the descriptions and the data source for all of the variables employed in our regression estimations. Table 2 reports descriptive statistics (means, standard deviations, minimums, and maximums) for all of the variable constructs based on the 563 observations employed in our regression estimations. Table 3 reports a correlation matrix where pairwise correlation coefficients are reported for all variables. While industry-R\&D rightly exhibits a pairwise correlation of 0.54 (slightly over the 0.5 benchmark for multi-collinearity concern) with IndustrySkilled-Labor (skilled labor is essential to R\&D in a sector), none of the other pairings between the control constructs - i.e., CFIUS-Investigation-Rate, Foreign-Acquirer-Experience, Domestic-AcquirerExperience, Unfriendly-Acquirer-Participation, Emerging-Acquirer-Participation, Industry-ValueAdded, Industry-Profit-Rate, Industry-Tax-Rate, and Industry-HHI - manifest a correlation above that benchmark. Furthermore, ancillary VIF and 
Table 1 Variable descriptions and data sources

\begin{tabular}{|c|c|}
\hline Variable & Description and source \\
\hline $\begin{array}{l}\text { Foreign-Acquirer- } \\
\text { Presence }\end{array}$ & $\begin{array}{l}\text { Value of foreign acquirer horizontal acquisitions of U.S. targets as a percentage of the total value of } \\
\text { horizontal acquisitions of U.S. targets } \\
\text { Source: Thomson SDC Platinum Database }\end{array}$ \\
\hline Merger-Policy-Risk & $\begin{array}{l}\text { Number of second-request-investigations as a percentage of total horizontal M\&A transactions } \\
\text { Source: Annual Reports to Congress on Hart-Scott-Rodino Antitrust Enforcement-U.S. FTC and DOJ }\end{array}$ \\
\hline $\begin{array}{l}\text { Merger-Policy- } \\
\text { Uncertainty }\end{array}$ & $\begin{array}{l}\text { Standard deviation in the number of annual second-request-investigations in the preceding } 5 \text { years } \\
\text { Source: Annual Reports to Congress on Hart-Scott-Rodino Antitrust Enforcement - U.S. FTC and DOJ }\end{array}$ \\
\hline CFIUS-Investigation-Rate & $\begin{array}{l}\text { Number of investigations conducted by CFIUS as a percentage of number of notified transactions to } \\
\text { CFIUS } \\
\text { Source: Annual Reports to Congress from the Committee on Foreign Investment in the United States - } \\
\text { U.S. Treasury Department }\end{array}$ \\
\hline $\begin{array}{l}\text { Foreign-Acquirer- } \\
\text { Experience }\end{array}$ & $\begin{array}{l}\text { Percentage of foreign acquirers with a previous U.S. acquisition experience in the preceding } 5 \text { years } \\
\text { Source: Thomson SDC Platinum Database }\end{array}$ \\
\hline $\begin{array}{l}\text { Domestic-Acquirer- } \\
\text { Experience }\end{array}$ & $\begin{array}{l}\text { Percentage of domestic acquirers with a previous U.S. acquisition experience in the preceding } 5 \text { years } \\
\text { Source: Thomson SDC Platinum Database }\end{array}$ \\
\hline $\begin{array}{l}\text { Unfriendly-Acquirer- } \\
\text { Participation }\end{array}$ & $\begin{array}{l}\text { Number of horizontal acquisitions of U.S. targets by unfriendly-nation acquirers as a percentage of the } \\
\text { total number of foreign acquirer horizontal acquisitions of U.S. targets } \\
\text { Source: Thomson SDC Platinum Database; YouGov Poll Database }\end{array}$ \\
\hline $\begin{array}{l}\text { Emerging-Acquirer- } \\
\text { Participation }\end{array}$ & $\begin{array}{l}\text { Number of horizontal acquisitions of U.S. targets by emerging market (i.e., non-OECD) acquirers as a } \\
\text { percentage of the total number of foreign acquirer horizontal acquisitions of U.S. targets } \\
\text { Source: Thomson SDC Platinum Database }\end{array}$ \\
\hline Industry-Value-Added & $\begin{array}{l}\text { Gross output less intermediate inputs (\$tn.) } \\
\text { Source: GDP by Industry Dataset from U.S. BEA }\end{array}$ \\
\hline Industry-R\&D & $\begin{array}{l}\text { R\&D capital expenditures divided by Industry-value-Added } \\
\text { Source: GDP by Industry Dataset from U.S. BEA }\end{array}$ \\
\hline Industry-Skilled-Labor & $\begin{array}{l}\text { College worker's compensation divided by compensation to all workers } \\
\text { Source: GDP by Industry Dataset from U.S. BEA }\end{array}$ \\
\hline Industry-Profit-Rate & $\begin{array}{l}\text { Gross operating surplus divided by Industry-value-Added } \\
\text { Source: GDP by Industry Dataset from U.S. BEA }\end{array}$ \\
\hline Industry-Tax- Rate & $\begin{array}{l}\text { Net tax on production \& imports divided by Industry-value-Added } \\
\text { Source: GDP by Industry Dataset from U.S. BEA }\end{array}$ \\
\hline Industry-HHI & $\begin{array}{l}\text { Herfindahl-Hirschman Index calculation with all available net sales data } \\
\text { Source: Compustat Database from Wharton Research Data Services. }\end{array}$ \\
\hline
\end{tabular}

Table 2 Descriptive statistics for the estimation sample

\begin{tabular}{|c|c|c|c|c|c|}
\hline Variable & Obs. & Mean & SD & Min & Max \\
\hline Foreign-Acquirer-Presence & 563 & 0.27 & 0.34 & 0.00 & 1.00 \\
\hline Merger-Policy-Risk & 563 & 0.11 & 0.18 & 0.00 & 1.00 \\
\hline Merger-Policy-Uncertainty & 563 & 0.82 & 0.72 & 0.00 & 4.24 \\
\hline CFIUS-Investigation-Rate & 563 & 0.11 & 0.17 & 0.00 & 0.46 \\
\hline Foreign-Acquirer-Experience & 563 & 0.23 & 0.28 & 0.00 & 1.00 \\
\hline Domestic-Acquirer-Experience & 563 & 0.45 & 0.11 & 0.00 & 0.83 \\
\hline Unfriendly-Acquirer-Participation & 563 & 0.02 & 0.07 & 0.00 & 1.00 \\
\hline Emerging-Acquirer-Participation & 563 & 0.10 & 0.21 & 0.00 & 1.00 \\
\hline Industry-Value-Added & 563 & 0.22 & 0.27 & 0.01 & 2.28 \\
\hline Industry-R\&D & 563 & 0.07 & 0.39 & 0.00 & 5.40 \\
\hline Industry-Skilled-Labor & 563 & 0.56 & 0.48 & 0.03 & 3.81 \\
\hline Industry-Profit-Rate & 563 & 0.41 & 0.21 & -1.41 & 0.93 \\
\hline Industry-Tax-Rate & 563 & 0.06 & 0.06 & -0.08 & 0.25 \\
\hline Industry-HHI & 563 & 0.11 & 0.10 & 0.01 & 1.00 \\
\hline
\end{tabular}




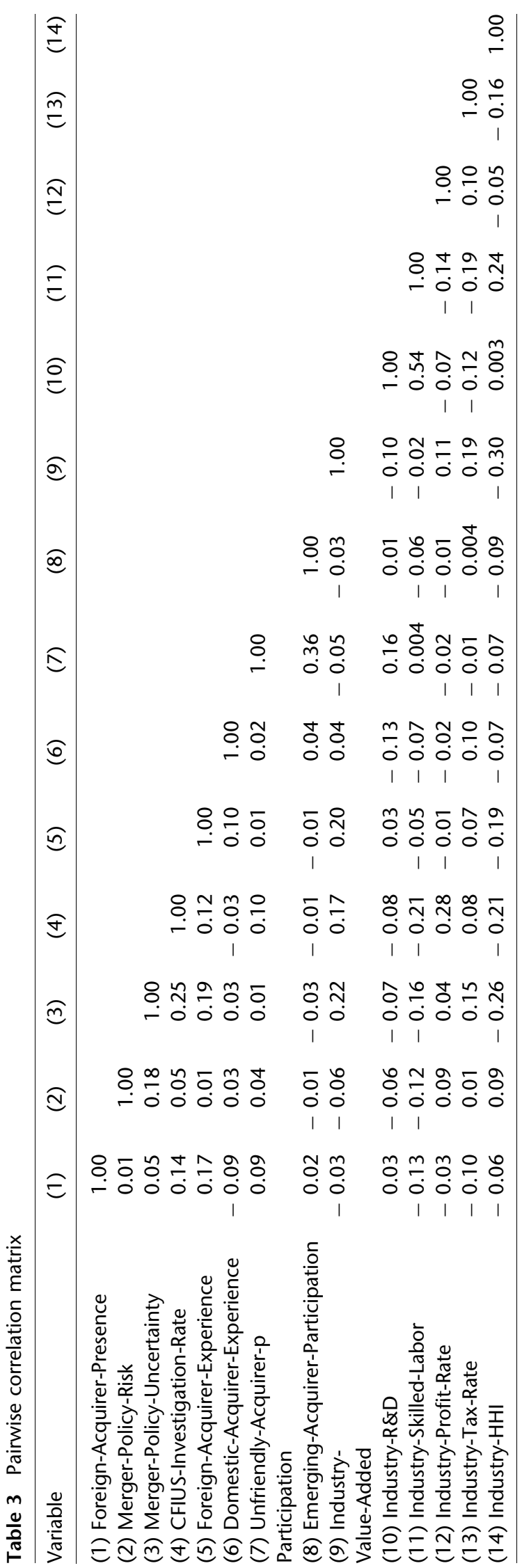

collinearity diagnostics indicate that the variance in the estimators is not substantially affected by the particular correlation between Industry-R\&D and Industry-Skilled-Labor.

\section{Estimation Strategy}

In following through on our theoretical priors, we aim to empirically investigate whether merger policy risk and uncertainty disproportionately deter the presence of foreign acquirers in the U.S. sectoral markets for corporate control. In doing so, we are able to employ panel-data techniques in our empirical testing. While we estimate a few different model specifications to establish robustness, our fullest regression specification takes the following form:

$$
\begin{aligned}
& \text { Foreign-Acquirer-Presence }{ }_{i t} \\
& \begin{aligned}
= & \beta_{0}+\beta_{1} \text { Merger-Policy-Risk } \sum_{k=1}^{2} t-k \\
& +\beta_{2} \text { Merger-Policy-Uncertainty } \sum_{k=1}^{5} t-k \\
& +\beta_{3} X_{i t-1}+\alpha_{I}+w_{t}+\varepsilon_{i t}
\end{aligned}
\end{aligned}
$$

where the subscripts $I$ and $t$ stand for industry and year, respectively, and $k$ allows for convenient expression. Vector $X$ refers to the series of lagged control constructs where lagging mitigates concerns with respect to reverse causality and simultaneity. The term $\left(\alpha_{I}\right)$ refers to industry-specific fixed effects; thus, we control for time-invariant industry-specific heterogeneity. The term $\left(w_{t}\right)$ refers to time-specific fixed effects; thus, we control for yearly shocks and trends that are common across industries. Furthermore, $\varepsilon_{i t}$ reflects an idiosyncratic error term. Per common practice with panel data, we will also employ robust standard errors clustered on the industry (Baum, Nichols, \& Schaffer, 2011).

The Merger-Policy-Risk construct involves taking the twice-lagged sum of second-request-investigations and dividing by the twice-lagged sum of horizontal M\&As in a particular industrial sector. Accordingly, we consider whether the investigation rate from the prior 2 years affects foreign acquirer presence in the current year. In capturing merger policy risk in this manner, we follow precedent in the merger policy deterrence literature (e.g., Clougherty et al., 2016; Clougherty \& Seldeslachts, 2013; Seldeslachts, Clougherty \& Barros, 2009) where enforcement actions are considered to involve a 2-year window in terms of benchmarking by market participants. In support of this approach, the FTC considers its enforcement efforts to involve a 2-year window in terms of benefits (Davies \& Majumdar, 2002). As an aside, our calculation of 
the parallel CFIUS-Investigation-Rate is conducted in an identical manner where the lagged 2-year investigation rate is employed for this control construct.

The Merger-Policy-Uncertainty construct involves calculating the standard deviation for the annual number of second-request-investigations taking place in the particular industrial sector over the preceding 5-year period. Accordingly, we consider whether volatility in the investigation activity from the prior 5 years affects foreign acquirer presence in the current year. While the pre-existing empirical literature provided strong priors with respect to the 2-year window for benchmarking the probability calculation involved with merger policy risk, Bloom (2014) underscores that there are few priors and data with respect to the appropriate time horizon for uncertainty measures. It seemed apparent to us that capturing uncertainty should extend beyond the lagged 2 years for calculating risk probabilities, but it was an open question as to the length of the appropriate time horizon. While the reported empirical results are based on considering the uncertainty in the various states for sector-level merger policy over the preceding 5 years, unreported empirical tests based on time horizons of three and four preceding years yield virtually identical empirical results.

The above methodological practices - employing the appropriate fixed effects for our sector-level data and lagging the explanatory constructs directly address the endogeneity issue, which according to Casson, Della Giusta, and Kambhampati (2010) has plagued the literature on countrylevel institutions and economic activities. Yet, one final econometric issue involves the fact that the dependent variable in the equation - ForeignAcquirer-Presence - exhibits a degree of left censoring and a slight degree of right censoring. The left censoring involves the clustering of zeros on the left side of the distribution for the dependent construct that customarily demands the appropriateness of a left-sided Tobit estimation (Tobin, 1958); thus, we will undertake a one-sided Tobit estimation in order to correct for the obvious left censoring. The additional right censoring involves some clustering of ones on the right side of the distribution for the dependent construct, and this calls for the appropriateness of a two-sided Tobit estimation (Long, 1997); thus, we will also undertake a two-sided Tobit estimation in order to correct for the presence of both left and right censoring. ${ }^{4}$
With the above econometric issues in mind, all of our regression models involve the appropriate sector-specific and year-specific fixed effects while undertaking a Tobit estimation that corrects for left censoring. Regression Model 1 represses the explanatory constructs of principal interest and simply reports the control variables in order to demonstrate the model specification. Regression Model 2 independently introduces the mergerPolicy-risk construct, while regression model 3 independently introduces the Merger-Policy-Uncertainty construct. Regression Model 4 reflects the full model specification (Eq. 1) in which the two main explanatory constructs, Merger-Policy-Risk and Merger-Policy-Uncertainty, are nested. Finally, regression Model 5 is identical to Model 4 with the exception that it involves a two-sided Tobit estimation that corrects for both left and right censoring.

\section{Empirical Results}

Table 4 reports the empirical results for our five regression models. The pseudo $R$-squares for the five Tobit estimations $(0.350,0.353,0.351,0.354$, and 0.329 , respectively, across the five models) indicate that the regression equation is reasonably well specified. It is important to highlight that pseudo $R^{2}$ tend to be systematically lower than standard $R^{2}$ values (McFadden, 1979). In addition to the goodness-of-fit statistics, the control variables also generally conform to expectations which also indicates a well-specified regression equation. In light of the consistency of the empirical results across the five different model specifications, we take a variable-by-variable approach in discussing the results.

We first discuss the empirical results for the two explanatory variables of principal interest; i.e., the impact of Merger-Policy-Risk on Foreign-AcquirerPresence (Hypothesis 1), and the impact of MergerPolicy-U uncertainty on Foreign-Acquirer-Presence (Hypothesis 2). In support of the first hypothesis, we find the coefficient estimate for the MergerPolicy-Risk variable to be negative and significant at the 0.1 percent level in all three regression models where this risk propensity construct is included (Models 2, 4, and 5). As such, increases in the tendency for antitrust authorities to investigate horizontal transactions in a sector tend to lead to decreased foreign acquirer participation in these M\&A markets in subsequent years. In terms of economic significance, a one-standard-deviation increase in Merger-Policy-Risk would lead on 
Table 4 Tobit estimation results

\begin{tabular}{|c|c|c|c|c|c|c|c|c|c|c|}
\hline \multirow[b]{3}{*}{ Merger-Policy-Risk $\sum_{k=1}^{2} \mathrm{t}-\mathrm{k}$} & \multicolumn{10}{|c|}{ Dependent variable: Foreign-Acquirer-Presence } \\
\hline & \multicolumn{2}{|c|}{ Model 1} & \multicolumn{2}{|c|}{ Model 2} & \multicolumn{2}{|c|}{ Model 3} & \multicolumn{2}{|c|}{ Model 4} & \multicolumn{2}{|c|}{ Model 5} \\
\hline & & & $\begin{array}{l}-0.19 \\
(0.01)\end{array}$ & $(0.00)$ & & & $\begin{array}{l}-0.17 \\
(0.01)\end{array}$ & $(0.00)$ & $\begin{array}{l}-0.18 \\
(0.01)\end{array}$ & $(0.00)$ \\
\hline${ }_{\text {Merger-Policy-Uncertainty }} \sum_{k=1}^{5} t-k$ & & & & & $\begin{array}{l}-0.05 \\
(0.001)\end{array}$ & $(0.00)$ & $\begin{array}{l}-0.04 \\
(0.001)\end{array}$ & $(0.00)$ & $\begin{array}{l}-0.04 \\
(0.001)\end{array}$ & $(0.00)$ \\
\hline CFIUS-Investigation-Rate $\sum_{k=1}^{2} t-k$ & $\begin{array}{l}-0.07 \\
(0.01)\end{array}$ & $(0.00)$ & $\begin{array}{l}-0.09 \\
(0.01)\end{array}$ & $(0.00)$ & $\begin{array}{l}-0.11 \\
(0.01)\end{array}$ & $(0.00)$ & $\begin{array}{l}-0.12 \\
(0.01)\end{array}$ & $(0.00)$ & $\begin{array}{l}-0.10 \\
(0.02)\end{array}$ & $(0.00)$ \\
\hline Foreign-Acquirer-Experience $\mathrm{t}_{\mathrm{t}-1}$ & $\begin{array}{l}0.23 \\
(0.002)\end{array}$ & $(0.00)$ & $\begin{array}{l}0.23 \\
(0.003)\end{array}$ & $(0.00)$ & $\begin{array}{l}0.22 \\
(0.002)\end{array}$ & $(0.00)$ & $\begin{array}{l}0.23 \\
(0.003)\end{array}$ & $(0.00)$ & $\begin{array}{l}0.25 \\
(0.003)\end{array}$ & $(0.00)$ \\
\hline Domestic-Acquirer-Experience $_{t-1}$ & $\begin{array}{l}-0.14 \\
(0.003)\end{array}$ & $(0.00)$ & $\begin{array}{l}-0.12 \\
(0.003)\end{array}$ & $(0.00)$ & $\begin{array}{l}-0.15 \\
(0.003)\end{array}$ & $(0.00)$ & $\begin{array}{l}-0.13 \\
(0.003)\end{array}$ & $(0.00)$ & $\begin{array}{l}-0.15 \\
(0.003)\end{array}$ & $(0.00)$ \\
\hline Unfriendly-Acquirer-Participation $_{\mathrm{t}-1}$ & $\begin{array}{l}0.24 \\
(0.02)\end{array}$ & $(0.00)$ & $\begin{array}{l}0.26 \\
(0.02)\end{array}$ & $(0.00)$ & $\begin{array}{l}0.24 \\
(0.02)\end{array}$ & $(0.00)$ & $\begin{array}{l}0.26 \\
(0.02)\end{array}$ & $(0.00)$ & $\begin{array}{l}0.37 \\
(0.02)\end{array}$ & $(0.00)$ \\
\hline Emerging-Acquirer-Participation $_{\mathrm{t}-1}$ & $\begin{array}{l}0.01 \\
(0.01)\end{array}$ & $(0.07)$ & $\begin{array}{l}0.02 \\
(0.01)\end{array}$ & $(0.01)$ & $\begin{array}{l}0.01 \\
(0.01)\end{array}$ & $(0.40)$ & $\begin{array}{l}0.02 \\
(0.01)\end{array}$ & $(0.06)$ & $\begin{array}{l}0.01 \\
(0.01)\end{array}$ & $(0.26)$ \\
\hline Industry-Value-Added $\mathrm{t}_{-1}$ & $\begin{array}{l}0.09 \\
(0.003)\end{array}$ & $(0.00)$ & $\begin{array}{l}0.13 \\
(0.003)\end{array}$ & $(0.00)$ & $\begin{array}{l}0.14 \\
(0.004)\end{array}$ & $(0.00)$ & $\begin{array}{l}0.16 \\
(0.004)\end{array}$ & $(0.00)$ & $\begin{array}{l}0.14 \\
(0.004)\end{array}$ & $(0.00)$ \\
\hline Industry-R\&D $\mathrm{D}_{\mathrm{t}-1}$ & $\begin{array}{l}0.07 \\
(0.002)\end{array}$ & $(0.00)$ & $\begin{array}{l}0.06 \\
(0.002)\end{array}$ & $(0.00)$ & $\begin{array}{l}0.08 \\
(0.002)\end{array}$ & $(0.00)$ & $\begin{array}{l}0.07 \\
(0.002)\end{array}$ & $(0.00)$ & $\begin{array}{l}0.06 \\
(0.002)\end{array}$ & $(0.00)$ \\
\hline Industry-Skilled-Labor ${ }_{t-1}$ & $\begin{array}{l}-0.23 \\
(0.002)\end{array}$ & $(0.00)$ & $\begin{array}{c}-0.23 \\
(0.002)\end{array}$ & $(0.00)$ & $\begin{array}{l}-0.23 \\
(0.002)\end{array}$ & $(0.00)$ & $\begin{array}{c}-0.23 \\
(0.002)\end{array}$ & $(0.00)$ & $\begin{array}{l}-0.27 \\
(0.002)\end{array}$ & $(0.00)$ \\
\hline Industry-Profit-Rate $\mathrm{t}_{\mathrm{t}-1}$ & $\begin{array}{l}-0.26 \\
(0.003)\end{array}$ & $(0.00)$ & $\begin{array}{l}-0.25 \\
(0.003)\end{array}$ & $(0.00)$ & $\begin{array}{l}-0.26 \\
(0.003)\end{array}$ & $(0.00)$ & $\begin{array}{l}-0.25 \\
(0.003)\end{array}$ & $(0.00)$ & $\begin{array}{l}-0.27 \\
(0.003)\end{array}$ & $(0.00)$ \\
\hline Industry-Tax-Rate $\mathrm{t}_{\mathrm{t}-1}$ & $\begin{array}{l}-3.05 \\
(0.01)\end{array}$ & $(0.00)$ & $\begin{array}{l}-3.10 \\
(0.01)\end{array}$ & $(0.00)$ & $\begin{array}{l}-3.13 \\
(0.01)\end{array}$ & $(0.00)$ & $\begin{array}{l}-3.16 \\
(0.01)\end{array}$ & $(0.00)$ & $\begin{array}{l}-3.11 \\
(0.01)\end{array}$ & $(0.00)$ \\
\hline Industry-HHI & $\begin{array}{c}-0.03 \\
(0.005)\end{array}$ & $(0.00)$ & $\begin{array}{l}0.02 \\
(0.01)\end{array}$ & $(0.00)$ & $\begin{array}{l}0.01 \\
(0.005)\end{array}$ & $(0.00)$ & $\begin{array}{l}0.05 \\
(0.01)\end{array}$ & $(0.00)$ & $\begin{array}{l}0.16 \\
(0.01)\end{array}$ & $(0.00)$ \\
\hline Constant & $\begin{array}{l}-2.00 \\
(0.001)\end{array}$ & $(0.00)$ & $\begin{array}{l}-2.01 \\
(0.001)\end{array}$ & $(0.00)$ & $\begin{array}{l}-2.01 \\
(0.001)\end{array}$ & $(0.00)$ & $\begin{array}{l}-2.01 \\
(0.001)\end{array}$ & $(0.00)$ & $\begin{array}{l}-2.07 \\
(0.002)\end{array}$ & $(0.00)$ \\
\hline Tobit censoring & Left-sided & & Left-sided & & Left-sided & & Left-sideo & & Two-side & \\
\hline Pseudo $R^{2}$ & 0.350 & & 0.353 & & 0.351 & & 0.354 & & 0.329 & \\
\hline
\end{tabular}

Robust standard errors clustered at the industry level are below the coefficient estimates and in parentheses; $p$ values are to the right in parentheses. All of the estimations involve 563 observations, as well as industry-specific and year-specific fixed effects.

average to a 3.1 (3.4) percentage point decrease in Foreign-Acquirer-Presence based on the more (less) conservative results in Model 4 (2). The empirical evidence then indicates that foreign investors are deterred more so than domestic investors from engaging in future acquisition activities when antitrust authorities increase the probabilities of incurring an investigation. Thus, in line with our first hypothesis, it appears that increases in merger policy risk negatively affect the relative presence of foreign acquirers in local M\&A markets.

In support of the second hypothesis, we find the coefficient estimate for the Merger-Policy-Uncertainty variable to be negative and significant at the 0.1 percent level in all three regression models where this uncertainty construct is included (Models 3,4 , and 5). As such, sectoral-level volatility in the propensity for antitrust authorities to investigate horizontal transactions tends to lead to decreased foreign acquirer participation in these local M\&A markets in subsequent years. In terms of economic significance, a one-standard-deviation increase in Merger-Policy-Uncertainty would lead on average to a 2.9 (3.6) percentage point decrease in Foreign-Acquirer-Presence based on the more (less) conservative results in Model 5 (3). The empirical evidence consequently indicates that foreign investors are deterred more so than domestic investors from engaging in future acquisition activities when antitrust authorities apply merger policy in a volatile manner from year to year. Thus, in line with our second hypothesis, it does appear that increases in merger policy uncertainty negatively affect the relative presence of foreign acquirers in local M\&A markets. 
Turning to a discussion of the empirical results for the control constructs in our regression specification, it is evident from all five model estimations that the controls (CFIUS-Investigation-Rate, Foreign-Acquirer-Experience, Domestic-AcquirerExperience, Unfriendly-Acquirer-Participation, Emerging-Acquirer-Participation, Industry-ValueAdded, Industry-R\&D, Industry-Skilled-Labor, Industry-Profit-Rate, Industry-Tax-Rate, and Industry-HHI) substantially affect the relative presence of foreign acquirers in the sectoral markets for corporate control. First, industries characterized by higher levels of CFIUS investigation activity tend to experience lower foreign acquirer presence in subsequent years, as the coefficient estimate conforms to our expectation by being statistically significant and negative in all five model estimations. In terms of economic significance, a onestandard-deviation increase in CFIUS-Investigation-Rate would lead on average to a 1.2 (2.0) percentage point decrease in Foreign-Acquirer-Experience based on the more (less) conservative empirical results in Model 1 (4).

Second, industries characterized by higher levels of foreign acquirer experience tend to have higher participation rates for foreign acquirers in the local M\&A markets, as the coefficient estimate conforms to our expectation by being statistically significant and positive in all five model estimations. In terms of economic significance, a one-standard-deviation increase in Foreign-Acquirer-Experience would lead on average to a 6.2 (7.0) percentage point increase in Foreign-Acquirer-Experience based on the more (less) conservative empirical results in Model 3 (5).

Third, industries characterized by higher levels of domestic acquirer experience tend to have lower participation rates for foreign acquirers in the local M\&A markets, as the coefficient estimate conforms to our expectation by being statistically significant and negative in all five model estimations. In terms of economic significance, a one-standard-deviation increase in Domestic-Acquirer-Experience would lead on average to a 1.3 (1.7) percentage point decrease in Foreign-Acquirer-Experience based on the more (less) conservative empirical results in Model 2 (5).

Fourth, industries characterized by higher levels of unfriendly acquirer participation tend to have higher participation rates for foreign acquirers in the local M\&A markets, as the coefficient estimate conforms to our expectation by being statistically significant and positive in all five model estimations. In terms of economic significance, a one- standard-deviation increase in Unfriendly-Acquirer-Participation would lead on average to a 1.7 (2.6) percentage point increase in ForeignAcquirer-Experience based on the more (less) conservative empirical results in Model 1 (5).

Fifth, industries characterized by higher levels of emerging acquirer participation tend to have higher participation rates for foreign acquirers in the local M\&A markets, as the coefficient estimate conforms to our expectation by being statistically significant and positive in all five model estimations. In terms of economic significance, a onestandard-deviation increase in Emerging-AcquirerParticipation would lead on average to a $0.2(0.4)$ percentage point increase in Foreign-Acquirer-Presence based on the more (less) conservative empirical results in Model 1 (4).

Sixth, industries characterized by higher levels of value added tend to experience higher foreign acquirer presence in subsequent years, as the coefficient estimate conforms to our expectation by being statistically significant and positive in all five model estimations. In terms of economic significance, a one-standard-deviation increase in Industry-Value-Added would lead on average to a 2.4 (4.3) percentage point increase in Foreign-AcquirerPresence based on the more (less) conservative empirical results in Model 1 (4).

Seventh, industries characterized by higher levels of $R \& D$ expenditures tend to experience higher foreign acquirer presence in subsequent years, as the coefficient estimate conforms to our expectation by being statistically significant and positive in all five model estimations. In terms of economic significance, a one-standard-deviation increase in Industry-R\&D would lead on average to a 2.3 (3.1) percentage point increase in Foreign-Acquirer-Presence based on the more (less) conservative empirical results in Model 2 (3).

Eighth, industries characterized by higher levels of skilled labor tend to experience lower foreign acquirer presence in subsequent years, as the coefficient estimate is statistically significant and negative in all five model estimations. In terms of economic significance, a one-standard-deviation increase in Industry-Skilled-Labor would lead on average to an 11.0 (13.0) percentage point decrease in Foreign-Acquirer-Presence based on the more (less) conservative empirical results in Model 1 (5). One explanation for this finding is that $R \& D$ expenditures capture the attractiveness of the U.S. sector for learning purposes; hence, the skilled labor tendencies of the sector captures the reality 
that such sectors will generally involve substantial prices.

Ninth, industries characterized by higher profit rates tend to experience lower foreign acquirer presence in subsequent years, as the coefficient estimate is statistically significant and negative in all five model estimations. In terms of economic significance, a one-standard-deviation increase in Industry-Profit-Rate would lead on average to a 5.3 (5.7) percentage point decrease in Foreign-Acquirer-Presence based on the more (less) conservative empirical results in Model 2 (5). One explanation for this finding is that the high profitability in a sector signals the presence of a competitive advantage for domestic firms.

Tenth, industries characterized by higher tax burdens tend to experience lower foreign acquirer presence in subsequent years, as the coefficient estimate is statistically significant and negative in all five model estimations. In terms of economic significance, a one-standard-deviation increase in Industry-Tax-Rate would lead on average to an 18.3 (19.0) percentage point decrease in Foreign-Acquirer-Presence based on the more (less) conservative empirical results in Model 1 (4). It appears then that tax burdens disproportionately affect foreign investors as compared to domestic investors.

Lastly, the market concentration construct (Industry-HHI) indicates that industries characterized by higher concentration tend to experience higher foreign acquirer presence in subsequent years after controlling for merger investigations. The coefficient estimate for Industry-HHI is statistically significant and negative (positive) in Model 1 (Models 2-5) which suggests that Industry-HHI proxies for the tenor of merger policy when that policy is not controlled for. Indeed, it stands to reason that merger policy scrutiny will be higher in industries characterized by higher concentration levels (Neven et al., 1998). In terms of economic significance, a one-standard-deviation increase in Industry-HHI would lead on average to a 0.1 (1.6) percentage point increase in Foreign-Acquirer-Experience based on the more (less) conservative empirical results in Model 3 (5).

\section{Robustness Testing}

We also engaged in a series of robustness tests to further explore the underlying mechanisms behind our theoretical priors and to establish some of the boundary conditions with respect to our results. Table 5 presents the empirical results for perhaps the most relevant additional analysis, as it underscores the role of information asymmetries in the conceptual framework leading to our theoretical priors. While our mainline empirical results in Table 4 control for the experience of foreign acquirers, Table 5 takes a different approach by breaking down whether it is experienced or inexperienced foreign acquirers which are principally deterred by merger policy. Specifically, Model 1 employs an "experienced Foreign-Acquirer-presence" dependent variable: the annual summed value of all foreign horizontal acquisitions (where the foreign acquirer has acquired a U.S. firm in the previous 5-year period) divided by the total value of all horizontal acquisitions in the sector. Furthermore, Model 2 employs an "Inexperienced Foreign-Acquirer-Presence" dependent variable: the annual summed value of all foreign horizontal acquisitions (where the foreign acquirer has not acquired a U.S. firm in the previous 5-year period) divided by the total value of all horizontal acquisitions in the sector. A review of the empirical results for merger policy risk and uncertainty in these two regression specifications yields evidence that conforms to the underlying mechanisms present in our theoretical priors.

First, merger policy risk - changes in the probability of detection in a particular industry - appears to deter both experienced and inexperienced foreign acquirers, but substantially deters experienced foreign acquirers. Our finding that merger policy risk affects experienced foreign investors more than inexperienced foreign investors is in line with discussions in the deterrence literature regarding which agents benchmark the relevant risk probabilities (e.g., Becker, 1968; Ehrlich, 1973; Zimmerman, $2004,2009)$. Specifically, experienced foreign acquirers appear to be more aware of the relevant probabilities of investigation; thus, they update their behavior based on changes in these probabilities in a manner akin to the agents in Becker's (1968) seminal work. Yet, inexperienced foreign acquirers tend to be less aware of the relevant probabilities of investigation; thus, they are less likely to update their behavior based on changes in these probabilities. Inexperienced foreign investors seemingly suffer from substantial information asymmetries, and are thus akin to the agents focused on by Zimmerman $(2004,2009)$ that do not follow Becker's conditional probability precepts.

Second, merger policy uncertainty - variability in the state of merger policy in a particular industry appears to deter inexperienced foreign acquirers, but does not deter experienced foreign acquirers. Please recall that our second hypothesis regarding 
Table 5 Tobit estimation results for Experienced and Inexperienced Foreign-Acquirer-Presence

\begin{tabular}{|c|c|c|c|c|}
\hline \multirow[b]{2}{*}{ Merger-Policy-Risk $\sum_{k=1}^{2} t-k$} & \multicolumn{2}{|c|}{$\begin{array}{c}\text { Model } 1 \\
\text { Experienced Foreign-Acquirer-Presence }\end{array}$} & \multicolumn{2}{|c|}{$\begin{array}{c}\text { Model } 2 \\
\text { Inexperienced Foreign-Acquirer-Presence }\end{array}$} \\
\hline & $\begin{array}{l}-0.27 \\
(0.01)\end{array}$ & $(0.00)$ & $\begin{array}{l}-0.05 \\
(0.01)\end{array}$ & $(0.00)$ \\
\hline Merger-Policy-Uncertainty $\sum_{k=1}^{5} t-k$ & $\begin{array}{l}0.005 \\
(0.001)\end{array}$ & $(0.00)$ & $\begin{array}{l}-0.02 \\
(0.001)\end{array}$ & $(0.00)$ \\
\hline CFIUS-Investigation-Rate $\sum_{k=1}^{2} t-k$ & $\begin{array}{l}0.11 \\
(0.01)\end{array}$ & $(0.00)$ & $\begin{array}{l}-0.18 \\
(0.01)\end{array}$ & $(0.00)$ \\
\hline Domestic-Acquirer-Experience $_{t-1}$ & $\begin{array}{l}0.08 \\
(0.002)\end{array}$ & $(0.00)$ & $\begin{array}{l}-0.35 \\
(0.003)\end{array}$ & $(0.00)$ \\
\hline Unfriendly-Acquirer-Participation $_{\mathrm{t}-1}$ & $\begin{array}{l}0.60 \\
(0.02)\end{array}$ & $(0.00)$ & $\begin{array}{l}-0.09 \\
(0.02)\end{array}$ & $(0.00)$ \\
\hline Emerging-Acquirer-Participation $_{\mathrm{t}-1}$ & $\begin{array}{l}-0.16 \\
(0.01)\end{array}$ & $(0.00)$ & $\begin{array}{l}0.12 \\
(0.01)\end{array}$ & $(0.00)$ \\
\hline Industry-Value-Added $\mathrm{t}_{-1}$ & $\begin{array}{l}0.04 \\
(0.002)\end{array}$ & $(0.00)$ & $\begin{array}{l}0.28 \\
(0.002)\end{array}$ & $(0.00)$ \\
\hline Industry-R\& $\mathrm{D}_{\mathrm{t}-1}$ & $\begin{array}{l}-1.25 \\
(0.01)\end{array}$ & $(0.00)$ & $\begin{array}{l}0.14 \\
(0.001)\end{array}$ & $(0.00)$ \\
\hline Industry-Skilled-Labor ${ }_{\mathrm{t}-1}$ & $\begin{array}{l}0.16 \\
(0.002)\end{array}$ & $(0.00)$ & $\begin{array}{l}-0.26 \\
(0.001)\end{array}$ & $(0.00)$ \\
\hline Industry-Profit-Rate $\mathrm{t}_{\mathrm{t}-1}$ & $\begin{array}{l}-0.13 \\
(0.002)\end{array}$ & $(0.00)$ & $\begin{array}{l}-0.01 \\
(0.002)\end{array}$ & $(0.04)$ \\
\hline Industry-Tax-Rate $\mathrm{t}_{\mathrm{t}-1}$ & $\begin{array}{l}-0.68 \\
(0.01)\end{array}$ & $(0.00)$ & $\begin{array}{l}-0.07 \\
(0.01)\end{array}$ & $(0.00)$ \\
\hline Industry- $\mathrm{HHI}_{\mathrm{t}-1}$ & $\begin{array}{l}0.24 \\
(0.01)\end{array}$ & $(0.00)$ & $\begin{array}{l}-0.26 \\
(0.01)\end{array}$ & $(0.00)$ \\
\hline Constant & $\begin{array}{l}-1.43 \\
(0.001)\end{array}$ & $(0.00)$ & $\begin{array}{l}-1.16 \\
(0.001)\end{array}$ & $(0.00)$ \\
\hline Number of observations & 504 & & 532 & \\
\hline Pseudo $R^{2}$ & 0.939 & & 0.487 & \\
\hline
\end{tabular}

Robust standard errors clustered at the industry level are below the coefficient estimates and in parentheses; $p$ values are to the right in parentheses. Both models involve industry-specific and year-specific fixed effects, as well as two-sided Tobit estimation. Since the two dependent variables factor the experience of foreign acquirers in a sector, we drop the Foreign-Acquirer-Experience control variable from Table 4.

the impact of merger policy uncertainty is almost completely based on the presence of information asymmetries. That is, information asymmetries are fundamental when it comes to the superior ability of domestic investors as compared to foreign investors in terms of predicting the future state of merger policy. Yet, the mechanisms underlying the first hypothesis regarding the impact of merger policy risk are only partly based on the presence of information asymmetries. With the above in mind, it is no surprise that the merger policy uncertainty effect only involves substantial deterrence with respect to inexperienced foreign acquirers, as information asymmetries - which will be most robust for inexperienced foreign investors - represent the intrinsic mechanism behind this theoretical prior. Furthermore, it is also no surprise that the merger policy risk effect involves deterrence with respect to both experienced and inexperienced foreign acquirers, as information asymmetries represent only a sub-part of the mechanisms behind this theoretical prior.

In addition to the above, we also engaged in robustness testing that further unpacked whether merger policy risk and uncertainty yielded heterogeneous deterrence effects in other contexts: foreign investors from friendly or unfriendly nations; and the periods before and after the 2008 financial crisis. First, we found that merge policy uncertainty involves relatively equal deterrence with respect to foreign acquirers hailing from both friendly and unfriendly nations. While merger policy risk substantially deters foreign acquirers from friendly nations, investors from unfriendly nations (i.e., China and Russia) are attracted by higher degrees of merger policy risk. This result is in line with recent patterns where investors from emerging markets are reported to be willing to take on risks that investors from developed markets are less willing to take on (e.g., Kumar, 2009; Luo \& Tung, 2007). 
Third, we also considered the effects of merger policy risk and uncertainty both before and after the 2008 financial crisis. There, we found that the policy risk effect principally derives from the precrisis period, while the policy uncertainty effect principally derives from the post-crisis period - a result in line with the increasing salience of political and economic uncertainty over the last decade (Bloom, 2014). Please see the online appendix for more details regarding this supplementary robustness testing.

\section{DISCUSSION AND CONCLUSION}

A number of observers have recognized that antitrust enforcement can generate consequences for foreign firms considering to invest in a particular host country. Moreover, the relatively thin empirical literature on this topic presents mixed findings as to whether antitrust enforcement promotes or deters inward FDI activities. Some scholars find evidence in support of a positive relationship between antitrust and inward FDI, as foreign investors value the levelplaying-field aspects of antitrust that mitigate liability of foreignness. Yet other scholars find evidence in support of a negative relationship between antitrust and inward FDI, as the application of antitrust might tend to be protectionist in nature. This debate with regard to the relationship between antitrust and foreign investment has long roots, although the relevance of this debate has heightened over the last two decades (e.g., Carletti, Spagnolo, Caiazza, \& Giannetti, 2010; Fingleton, 2009). With the aim of bringing some clarity to the above discourse, our conceptual framework generates two theoretical contentions.

Our first theoretical prior contends that merger policy risk negatively affects the relative presence of foreign acquirers in local M\&A markets. Merger policy risk likely involves a larger deterrence effect with respect to foreign investor activities as compared to domestic investor activities due to the presence of three mechanisms. First, foreign investors disproportionately experience the costs involved with navigating the merger review process due to their inherent liabilities and information asymmetries. Second, foreign investors tend to be more risk averse as compared to domestic investors, thus generating more cautious investment behavior. Third, antitrust agencies potentially exhibit bias and protectionism by disproportionately targeting and scrutinizing foreign investor acquisition activities. These three mechanisms first lead to reduced foreign investor participation in local M\&A markets, and ultimately lead to the deterrence of future cross-border acquisitions as foreign investors refrain from such activities due to the presence of policy risks.

In a similar vein, our second theoretical prior contends that merger policy uncertainty negatively affects the relative presence of foreign acquirers in local M\&A markets. Merger policy uncertainty likely involves a larger deterrence effect with respect to foreign investor activities as compared to domestic investor activities due to the presence of substantial information asymmetries on the part of foreign investors. Investors hailing from foreign countries face particular disadvantages with respect to properly assessing the policy uncertainties associated with alterations in the future states of merger review. Thus, higher degrees of policy uncertainty regarding the future strength and tenor of the merger review process lead to reduced foreign investor participation in local M\&A markets. In addition to negatively impacting foreign acquisitions of indigenous firms, this leads to the deterrence of future cross-border acquisitions as foreign investors refrain from such activities due to the presence of policy uncertainties.

In testing the above theoretical priors regarding the impact of merger policy enforcement on foreign acquirer participation in the local markets for corporate control, we also advance the empirical literature on this topic. In particular, sectorallevel analysis in the U.S. context improves upon the country-level analysis that has been characteristic of previous work. In order to follow through on the above aims, we employ data on merger policy enforcement and foreign acquirer presence in 53 U.S. industrial sectors over the 2002-2017 period. The U.S. context represents a hard case to establish a negative relationship between merger policy enforcement and foreign acquirer presence due to the government's strong institutional commitment to antitrust principles (e.g., Clougherty, 2001, 2005; Viscusi et al., 1995; White, 2009) and to inward FDI openness (e.g., Baltz, 2017; Golub, 2009; Grosse \& Trevino, 1996; Peng et al., 2008). Employing panel-data econometric techniques that control for the appropriate fixed effects, our empirical results indicate that higher levels of merger policy risk and merger policy uncertainty disproportionately deter foreign acquirer participation in the local markets for corporate control. Accordingly, the application and enforcement of U.S. merger policy contribute to de-globalization in the sense that foreign investor activity generally 
decreases more so than domestic investor activity. Moreover, our empirical results suggest that the enforcement of merger policy in other nations where there is likely to be less of a commitment to antitrust principles - will also represent a deterrent to foreign investment activities.

We are mindful, however, that our study involves several limitations that encourage future research on this topic that could extend our understanding of how merger policy affects foreign investment activities. First, our data on U.S. merger policy does not allow the differentiating of investigations of foreign acquirers from investigations of domestic acquirers; thus, we are unable to establish whether foreign investors are disproportionately targeted or held to higher standards as compared to domestic investors. Future empirical work that makes such distinctions will be better able to establish whether it is bias in the application of U.S. merger policy or the asymmetric effects of merger policy on foreign investors that ultimately leads to the disproportional deterrence of foreign acquirers in local $M \& A$ markets. Second, antitrust investigations represent a substantial holdup for acquiring firms, as they involve costs, delays, and uncertainty with respect to when and whether transactions can be achieved. However, it would be healthy for future empirical work to complement our evidence on investigation activities with evidence on the application of structural remedies and prohibitions by antitrust authorities. Third, the control of mergers represents the most-important element of a national commitment to competition policy, and is the most salient element with respect to foreign acquirer activities. Nevertheless, obtaining sector-level data on the other two elements of competition policy - i.e., price collusion and abuse of dominance - would allow factoring the full breadth of this policy and its effect on inward FDI activities. Fourth, considering the sector-level relationship between U.S. merger policy investigations and foreign acquirer presence involves methodological merits due to the U.S. representing a hard case for which to establish protectionism in antitrust. Yet, extending this study to other national jurisdictions would certainly be advisable, as it would allow a more complete factoring of how merger policy affects foreign acquirer activities in the cross-national context. Fifth, it is certainly proper to match our sector-level data on merger policy investigations with the sector-level participation of foreign investors in the local markets for corporate control. That said, future empirical work might be able to consider the impact of sector-level enforcement on transaction-level details akin to the studies that consider firm-level responses to country-level factors. Sixth, we provide evidence that merger policy enforcement deters foreign acquirer participation in local M\&A markets; however, increases in merger control may also result in enhanced Greenfield activities if such activities substitute for crossborder acquisitions. Future work that considers such substitutive - or potentially complementary - relationships is certainly called for.

Our empirical findings do, nevertheless, yield implications for the IB literature on host-country institutional characteristics and foreign investment activity. We follow through on Brewer's (1993) call to consider the relevance of competition policies as a factor affecting inward FDI activities. Indeed, competition policy involves the potential to either increase or decrease foreign investment; thus, it behooves IB researchers to ascertain the directionality of this relationship. As Grosse and Behrman (1992: 115) observe, the market power aspects of MNE activities have "given rise to government policies, but usually not differentiated from policies towards domestic firms". While a number of IB scholars have called for increased attention to competition policies - and merger policy in particular when analyzing foreign investments, Brewer's (1993: 104) observation that "there has not been a sustained attempt in the literature to develop the implications of antitrust policies for FDI" still rings true. We hope this work spurs IB scholars to further consider the implications of antitrust - and regulatory policies in general - on foreign investment activities.

Our empirical results also yield normative policy implications with respect to the enforcement of merger policy and the encouragement of inward-FDI activities. Most obviously, our results indicate that it is lax enforcement of merger control which will generally encourage increased foreign acquirer participation in local M\&A markets. Moreover, our finding of a negative relationship between merger policy investigations and foreign acquirer presence is consistent with U.S. merger policy being protectionist. Protectionist U.S. merger policy certainly contradicts the spirit behind the consumer welfare criterion that is written and codified into U.S. antitrust law (Kirkwood \& Lande, 2008; Neven \& Röller, 2005). Yet, we should underscore that our empirical results simply indicate that the merger review process is protectionist in effect, as foreign investors - as compared to domestic investors - are 
disproportionately deterred by higher levels of merger policy risk and uncertainty. Our empirical testing does not establish whether foreign investors forsake participation in local M\&A markets due to their inherent sensitivity to situations where they lack local information, legitimacy, and contacts, or due to their being more-frequently targeted as compared to domestic investors. Put simply, the empirical testing cannot shed evidence on whether U.S. merger policy enforcement is protectionist in intent.

Finally, our study brings some hard evidence to the literature, focusing on how the enforcement of competition policies affects foreign investor activities. While the pre-existing literature based on country-level studies presents mixed empirical findings, our sector-level empirical analysis grounded in the U.S. context yields strong evidence in favor of merger policy risk and uncertainty negatively affecting foreign acquirers more than domestic acquirers. By helping to start to define the true relationship between competition policies and inward FDI, we respond to calls by a number of IB scholars for increased attention to antitrust issues when analyzing foreign investments. The main implication of this paper is thus simple but important: the proliferation of merger policy to over 70 nations in the last few decades has likely deterred foreign acquirer participation in local M\&A markets in the cross-national context for global business, and thereby partly contributed to de-globalization.

\section{ACKNOWLEDGEMENTS}

We wish to thank Robert Grosse (our editor), two anonymous referees, Joe Mahoney, Alain Verbeke, and seminar participants at the AIB in Minneapolis, AOM in Boston, and the University of Illinois at Urbana-Champaign for insightful comments and suggestions. We also appreciate the research assistance of Thomas DeBerge.

\section{NOTES}

${ }^{1}$ While merger policy generally represents the most-substantial hurdle for foreign investors and price-fixing is a behavioral issue that should not bar access to a market, the recent difficulties for U.S. high-tech firms with the European Commission have involved anti-competitive practices and abuse of dominance. Hence, the rise of 'winner-take-all' markets, like in high tech, may increase the salience of this particular element of competition policy for foreign investors.

${ }^{2}$ Stata does not generally drop panels where the dependent and explanatory variables do not exhibit variation across the panel, though these observations do not affect coefficient estimates when undertaking within-estimations. The rationale behind this Stata practice is that the inclusion of these panel observations allows for more precision in estimation.

${ }^{3}$ The Trump administration's recent attempt to block AT\&T's purchase of Time Warner - a vertical merger - has received a great deal of scrutiny in policy circles for this very reason. If actually driven by anti-competitive concerns, this action by the DOJ would signal a substantial shift in the nature of U.S. antitrust policy, although others consider the ultimate fate of CNN (a subsidiary of Time Warner) to be the real cause behind DOJ scrutiny. See Kang and de la Merced (2017) for more details.

${ }^{4}$ The censored nature of our dependent variable mandates employing Tobit estimations in order to consistently estimate the coefficient estimates (Wooldridge, 2002). The panel nature of our data also requires the inclusion of fixed industry-specific and year-specific effects, yet it is commonly understood that the consistency of such coefficients in the context of panel data has not been established. However, Greene's (2004) Monte Carlo experiments indicate that logit and probit estimations are far more vulnerable to such biases as compared to Tobit estimations. In unreported empirical testing, we ran first-differencing models (where the dependent construct takes on a normal distribution) to establish the robustness of our reported empirical results.

\section{REFERENCES}

Aktas, N., Bodt, E., \& Roll, R. 2007. Is European M\&A regulation protectionist? The Economic Journal, 117(522): 1096-1121.
Baillie, R. T., \& DeGennaro, R. P. 1990. Stock returns and volatility. Journal of Financial and Quantitative Analysis, 25(2): 203-214. 
Baker, S. R., Bloom, N., \& Davis, S. J. 2016. Measuring economic policy uncertainty. The Quarterly Journal of Economics, 131(4): 1593-1636.

Baltz, M. J. 2017. Institutionalizing neoliberalism: CFIUS and the governance of inward foreign direct investment in the United States since 1975. Review of International Political Economy, 24(5): 859-880.

Bascle, G. 2008. Controlling for endogeneity with instrumental variables in strategic management research. Strategic Organization, 6(3): 285-327.

Baum, C. F., Nichols, A., \& Schaffer, M. E. 2011. Evaluating oneway and two-way cluster-robust covariance matrix estimates. Talk given at the German Stata Users Group Meeting. July 2011, http://fmwww.bc.edu/RePEc/dsug2011/desug11_schaffer. pdf.

Becker, G. S. 1968. Crime and punishment: An economic approach. Journal of Political Economy, 76(2): 169-217.

Bessembinder, H., \& Seguin, P. J. 1992. Futures-trading activity and stock price volatility. The Journal of Finance, 47(5): 2015-2034.

Bloom, N. 2014. Fluctuations in uncertainty. Journal of Economic Perspectives, 28(2): 153-176.

Boddewyn, J. J. 1988. Political aspects of MNE theory. Journal of International Business Studies, 19(3): 341-363.

Bonaime, A., Gulen, H., \& Ion, M. 2018. Does policy uncertainty affect mergers and acquisitions? Journal of Financial Economics, 129(3): 531-558.

Brewer, T. L. 1993. Governments, policies, market imperfections, and foreign direct investment. Journal of International Business Studies, 24(1): 101-120.

Bris, A., Brisley, N., \& Cabolis, C. 2008. Adopting better corporate governance: Evidence from cross-border mergers. Journal of Corporate Finance, 14(3): 224-240.

Bris, A., Cabolis, C., \& Janowski, V. 2007. The effect of merger laws on merger activity: International evidence. In G. N. Gregoriou, \& L. Renneboog (Eds.), Corporate governance and regulatory impact on mergers and acquisitions: Research and analysis on activity worldwide since 1990: 15-41. Cambridge, MA: Academic.

Brooks, D. H. 2007. Industrial and competition policy: Conflict or complementarity? Asian Development Bank Institute (ADBI) Research Policy Brief No. 24. Tokyo, Japan.

Brouthers, K. D., Brouthers, L. E., \& Werner, S. 2008. Real options, international entry mode choice and performance. Journal of Management Studies, 45(5): 936-960.

Buccirossi, P., Ciari, L., Duso, T., Spagnolo, G., \& Vitale, C. 2013. Competition policy and productivity growth: An empirical assessment. Review of Economics and Statistics, 95(4): 1324-1336.

Buckley, P. J., \& Casson, M. C. 1996. An economic model of international joint venture strategy. Journal of International Business Studies, 27(5): 849-876.

Caporaso, J. A., \& Levine, D. P. 1992. Theories of political economy. Cambridge: Cambridge University Press.

Carletti, E., Spagnolo, G., Caiazza, S., \& Giannetti, C. 2010. Banking competition in Europe: Antitrust authorities at work in the wake of the financial crisis. World Competition, 33(4): 615-642

Casson, M. C., Della Giusta, M., \& Kambhampati, U. S. 2010. Formal and informal institutions and development. World Development, 38(2): 137-141.

Clarke, J. L. 2003. Competition policy and foreign direct investment. Paper presented at the European Trade Study Group (ETSG) fifth annual conference. Madrid, Spain.

Clougherty, J. A. 2001. Globalization and the autonomy of domestic competition policy: An empirical test on the world airline industry. Journal of International Business Studies, 32(3): 459-478.

Clougherty, J. A. 2005. Antitrust holdup source, cross-national institutional variation, and corporate political strategy implications for domestic mergers in a global context. Strategic Management Journal, 26(8): 769-790.

Clougherty, J. A., Duso, T., Lee, M., \& Seldeslachts, J. 2016. Effective European antitrust: Does EC merger policy generate deterrence? Economic Inquiry, 54(4): 1884-1903.

Clougherty, J. A., \& Seldeslachts, J. 2013. The deterrence effects of US merger policy instruments. The Journal of Law, Economics, and Organization, 29(5): 1114-1144.

Coate, M. B., Higgins, R. S., \& McChesney, F. S. 1990. Bureaucracy and politics in FTC merger challenges. The Journal of Law \& Economics, 33(2): 463-482.

Conybeare, J., \& Kim, D. H. 2010. Barbarians at the gates: State control of global mergers and acquisitions. The World Economy, 33(9): 1175-1199.

Davies, S., \& Majumdar, A. 2002. The development of targets for consumer savings arising from competition policy. London: Office of Fair Trading.

Delios, A., \& Henisz, W. J. 2000. Japanese firms' investment strategies in emerging economies. The Academy of Management Journal, 43(3): 305-323.

Delios, A., \& Henisz, W. J. 2003a. Policy uncertainty and the sequence of entry by Japanese firms, 1980-1998. Journal of International Business Studies, 34(3): 227-241.

Delios, A., \& Henisz, W. J. 2003b. Political hazards, experience, and sequential entry strategies: The international expansion of Japanese firms, 1980-1998. Strategic Management Journal, 24(11): 1153-1164.

Deloitte \& Touche. 2007. The deterrent effect of competition enforcement by the OFT. Report No. 962. London: Office of Fair Trading.

Desai, M., Villalonga, B., \& Veblen, M. 2005. Antitrust regulations in a global setting: The EU investigation of the GE/ Honeywell merger. Harvard Business School Case, 204-081.

Deshpande, S., Svetina, M., \& Zhu, P. 2016. The impact of European Commission merger regulation on US domestic M\&As. Journal of Multinational Financial Management, 36(1): $1-15$.

Dinc, I. S., \& Erel, I. 2013. Economic nationalism in mergers and acquisitions. The Journal of Finance, 68(6): 2471-2514.

Eden, L. 1994. Multinationals in North America: An introduction to the issues. In L. Eden (Ed.), Multinationals in North America: 1-21. Calgary: The University of Calgary Press.

Ehrlich, I. 1973. Participation in illegitimate activities: A theoretical and empirical investigation. Journal of Political Economy, 81(3): 521-565.

Evenett, S. J. 2002. How much have merger review laws reduced cross border mergers and acquisitions?. In W. K. Rowley (Ed.), International merger control: Prescriptions for convergence. London: International Bar Association.

Evenett, S. J. 2003. Competition law and the investment climate in developing countries. World Development Report Background Papers. Washington, DC: World Bank.

Faith, R. L., Leavens, D. R., \& Tollison, R. D. 1982. Antitrust pork barrel. The Journal of Law \& Economics, 25(2): 329-342.

Farrell, J. 2003. Negotiation and merger remedies: Some problems. In F. Leveque, \& H. Shelankski (Eds.), Merger remedies in American and European Union competition law: 95-105. Cheltenham: Edward Elgar Publishing.

Fingleton, J. 2009. Competition policy in troubled times. Speech given at the Annual Charles River Associates Conference. Brussels.

Fitzpatrick, M. 1983. The definition and assessment of political risk in international business: A review of the literature. Academy of Management Review, 8(2): 249-254.

Francois, J., \& Horn, H. 2007. Antitrust in open economies. In V. Ghosal, \& J. Stennek (Eds.), The political economy of antitrust (contributions to economic analysis, volume 282): 463-483. Bingley: Emerald.

French, K. R., Schwert, G. W., \& Stambaugh, R. F. 1987. Expected stock returns and volatility. Journal of Financial Economics, 19(1): 3-29. 
Galloway, J. 2009. Convergence in international merger control. The Competition Law Review, 5(2): 179-192.

Gehrig, T. 1993. An information based explanation of the domestic bias in international equity investment. The Scandinavian Journal of Economics, 95(1): 97-109.

George, E., Chattopadhyay, P., Sitkin, S. B., \& Barden, J. 2006. Cognitive underpinnings of institutional persistence and change: A framing perspective. Academy of Management Review, 31(2): 347-365.

Golub, S. S. 2009. Openness to foreign direct investment in services: An international comparative analysis. The World Economy, 32(8): 1245-1268.

Gordon, R. H., Bovenberg, A. L. 1996. Why is capital so immobile internationally? Possible explanations and implications for capital income taxation. The American Economic Review, 86(5): 1057-1075.

Graham, E. M., \& Warner, M. A. 1994. Multinationals and competition policy in North America. In L. Eden (Ed.), Multinationals in North America: 463-501. Calgary: The University of Calgary Press.

Greene, W. 2004. The behaviour of the maximum likelihood estimator of limited dependent variable models in the presence of fixed effects. The Econometrics Journal, 7(1): 98-119.

Grosse, R. 1985. An imperfect competition theory of the MNE. Journal of International Business Studies, 16(1): 57-80.

Grosse, R. 2005. The bargaining view of government-business relations. In R. Grosse (Ed.), International business and government relations in the 21st century: 273-290. Cambridge: Cambridge University Press.

Grosse, R., \& Behrman, J. N. 1992. Theory in international business. Transnational Corporations, 1(1): 93-126.

Grosse, R., \& Trevino, L. J. 1996. Foreign direct investment in the United States: An analysis by country of origin. Journal of International Business Studies, 27(1): 139-155.

Grosse, R., \& Trevino, L. J. 2005. New institutional economics and FDI location in Central and Eastern Europe. Management International Review, 45(2): 123-145.

Hemphill, T. A. 2010. The 'new protectionism': Industrial policy barriers to cross-border mergers and acquisitions. Competition \& Change, 14(2): 124-148.

Henisz, W. J. 2000. The institutional environment for economic growth. Economics and Politics, 12(1): 1-31.

Henisz, W. J. 2004. Political institutions and policy volatility. Economics and Politics, 16(1): 1-27.

Henisz, W. J., \& Delios, A. 2001. Uncertainty, imitation, and plant location: Japanese multinational corporations, 1990-1996. Administrative Science Quarterly, 46(3): 443-475.

Hennart, J. F., \& Reddy, S. 1997. The choice between mergers/ acquisitions and joint ventures: The case of Japanese investors in the United States. Strategic Management Journal, 18(1): $1-12$.

Hitt, M. A., Li, D., \& Xu, K. 2016. International strategy: From local to global and beyond. Journal of World Business, 51(1): $58-73$.

Horton, T. J. 2016. Antitrust or industrial protectionism? Emerging international issues in China's anti-monopoly law enforcement efforts. Santa Clara Journal of International Law, 14(1): 109-142.

Hymer, S. 1970. The efficiency (contradictions) of multinational corporations. The American Economic Review, 60(2): 441-448.

Hymer, S. 1976 [1960]. The international operations of national firms: A study of direct foreign investment. Cambridge, MA: MIT press.

Jorde, T. M., \& Teece, D. J. 1990. Innovation and cooperation: Implications for competition and antitrust. Journal of Economic Perspectives, 4(3): 75-96.

Kang, C., \& de la Merced, M. J. 2017. Justice department sues to block AT\&T-Time Warner merger. The New York Times. Retrieved December 8, 2017, from https://www.nytimes. com/2017/11/20/business/dealbook/att-time-warner-merger. html.
Kindleberger, C. P. 1969. American business abroad. New Haven, CT: Yale University Press.

Kirkwood, J. B., \& Lande, R. H. 2008. The fundamental goal of antitrust: Protecting consumers, not increasing efficiency. Notre Dame Law Review, 84(1): 191-243.

Knight, F. H. 1921. Risk, uncertainty, and profit. New York: Houghton and Mifflin.

Kobrin, S., Basek, J., Blank, S., \& La Palombara, J. 1980. The assessment and evaluation of noneconomic environments by American firms. Journal of International Business Studies, 11(1): 32-47.

Kobrin, S. J. 1979. Political risk: A review and reconsideration. Journal of International Business Studies, 10(1): 67-80.

Kovacic, E. E. 2003. The modern evolution of U.S. competition policy enforcement norms. Antitrust Law Journal, 71(2): 377-478.

Kumar, N. 2009. How emerging giants are rewriting the rules of M\&A. Harvard Business Review, 87(5): 115-121.

Kwoka, J. E. 1999. Commitment to competition: An assessment of antitrust agency budgets since 1970. Review of Industrial Organization, 14(4): 295-302.

Li, Q. 2007. Democracy, antitrust regulation, and cross-border mergers and acquisitions. Paper presented at the workshop on political competition and government policy: 4-5. Raleigh, NC.

Liesch, P. W., Welch, L. S., \& Buckley, P. J. 2011. Risk and uncertainty in internationalisation and international entrepreneurship studies: Review and conceptual development. Management International Review, 51(6): 851873.

Long, J. S. 1997. Regression models for categorical and limited dependent variables, Thousand Oaks, CA: Sage.

Luo, Y., \& Tung, R. L. 2007. International expansion of emerging market enterprises: A springboard perspective. Journal of International Business Studies, 38(4): 481-498.

McFadden, D. 1979. Quantitative methods for analysing travel behaviour of individuals: Some recent developments. In D. Hensher \& P. Stopher (Eds.), Behavioural travel modelling: 279-318. London: Croom Helm.

Mehta, M. N., Srinivasan, S., \& Zhao, W. 2020. The politics of M\&A antitrust. Journal of Accounting Research, 58(1), 5-53.

Miller, K. D. 1993. Industry and country effects on managers' perceptions of environmental uncertainties. Journal of International Business Studies, 24(4): 693-714.

Moe, T. M. 1987. An assessment of the positive theory of 'congressional dominance'. Legislative Studies Quarterly, 12(4): 475-520.

Motta, M. 2004. Competition policy: Theory and practice. Cambridge: Cambridge University Press.

Neven, D. I., Papandropoulos, P., \& Seabright, P. 1998. Trawling for minnows: European competition policy and agreements between firms. London: Centre for Economic Policy Research.

Neven, D. J., \& Röller, L. H. 2005. Consumer surplus vs. welfare standard in a political economy model of merger control. International Journal of Industrial Organization, 23(9-10): 829-848.

Oliveira, G., Hochstetler, R., \& Kalil, C. 2001. Competition policy and foreign direct investment: Possible relationships and aspects from the recent Brazilian experience. Transnational Corporations, 10(1): 69-87.

Peng, M. W., Sun, S. L., Pinkham, B., \& Chen, H. 2009. The institution-based view as a third leg for a strategy tripod. Academy of Management Perspectives, 23(3): 63-81.

Peng, M. W., Wang, D. Y. L., \& Jiang, Y. 2008. An institutionbased view of international business strategy: A focus on emerging economies. Journal of International Business Studies, 39(5): 920-936.

Penrose, E. T. 1972. The theory of the growth of the firm. Oxford: Blackwell.

Porter, M. E. 1998. Clusters and the new economics of competition. Harvard Business Review, 76(6): 77-90. 
Rivoli, P., \& Salorio, E. 1996. Foreign direct investment and investment under uncertainty. Journal of International Business Studies, 27(2): 335-357.

Rodriguez, A. E., \& Menon, A. 2010. The limits of competition policy: The shortcomings of antitrust in developing and reforming economies. The Hague: Kluwer.

Rugman, A. M., \& Verbeke, A. 2001. Multinational enterprises and public policy. In A. M. Rugman \& T. L. Brewer (Eds.), The Oxford handbook of international business: 818-842. Oxford: Oxford University Press.

Seldeslachts, J., Clougherty, J. A., \& Barros, P. P. 2009. Settle for now but block for tomorrow: The deterrence effects of merger policy tools. The Journal of Law \& Economics, 52(3): 607-634.

Spar, D. L. 2001. National policies and domestic politics. In A. M. Rugman \& T. L. Brewer (Eds.), The Oxford handbook of international business: 206-231. Oxford: Oxford University Press.

The Economist. 2001. GE/Honeywell: Welch squelched. June 23: 73.

Tobin, J. 1958. Estimation of relationships for limited dependent variables. Econometrica, 26(1): 24-36.

Vachris, M. A. 1996. Federal antitrust enforcement: A principalagent perspective. Public Choice, 88(3-4): 223-238.

Vadlamannati, K. C. 2012. Impact of political risk on FDI revisited-An aggregate firm-level analysis. International Interactions, 38(1): 111-139.

Viscusi, W. K., Vernon, J. M., \& Harrington, J. E. 1995. Economics of regulation and antitrust. Cambridge, MA: MIT Press.

Weingast, B. R., \& Moran, M. J. 1983. Bureaucratic discretion or congressional control? Regulatory policy making by the
Federal Trade Commission. Journal of Political Economy, 91(5): 765-800.

Werner, S., Brouthers, L. E., \& Brouthers, K. D. 1996. International risk and perceived environmental uncertainty: The dimensionality and internal consistency of Miller's measure. Journal of International Business Studies, 27(3): 571-587.

Weston, J. F., \& Sorge, B. W. 1972. International managerial finance. Homewood, IL: Richard D. Irwin.

White, L. J. 2009. Introduction: Antitrust and regulatory update. Review of Industrial Organization, 35(4): 315-316.

Williamson, O. E. 1985. The economic institutions of capitalism: Firms, markets, relational contracting. New York, NY: Free Press.

Wooldridge, J. M. 2002. Econometric analysis of cross section and panel data. Cambridge, MA: MIT Press.

Wooldridge, J. M. 2013. Introductory econometrics: A modern approach. Mason, $\mathrm{OH}$ : Thomson-South Western.

Zaheer, S. 1995. Overcoming the liability of foreignness. The Academy of Management Journal, 38(2): 341-363.

Zhang, X., \& Zhang, V. Y. 2010. Chinese merger control: Patterns and implications. Journal of Competition Law \& Economics, 6(2): 477-496.

Zimmerman, P. R. 2004. Estimates of the deterrent effect of alternative execution methods in the United States: 1978-2000. American Journal of Economics and Sociology, 65(4): 909-941.

Zimmerman, P. R. 2009. Statistical variability and the deterrent effect of the death penalty. American Law and Economics Review, 11(2): 370-398.

\section{APPENDIX}

See Table 6.

Table 6 Number of observations and means for the three primary variables for the 53 sectors

\begin{tabular}{|c|c|c|c|c|}
\hline \multirow[t]{2}{*}{ Sector name } & \multirow[t]{2}{*}{ Obs. } & \multicolumn{3}{|c|}{ Mean } \\
\hline & & $\begin{array}{l}\text { Foreign-Acquirer- } \\
\text { Presence }\end{array}$ & $\begin{array}{l}\text { Merger-Policy- } \\
\text { Risk }\end{array}$ & $\begin{array}{l}\text { Merger-Policy- } \\
\text { Uncertainty }\end{array}$ \\
\hline Farms & 8 & 0 & 0 & 0 \\
\hline Oil and gas extraction & 14 & 0.16 & 0.02 & 0.31 \\
\hline Mining, except oil and gas & 14 & 0.41 & 0.20 & 0.83 \\
\hline Support activities for mining & 13 & 0.35 & 0.15 & 1.00 \\
\hline Utilities & 14 & 0.30 & 0.04 & 1.07 \\
\hline Construction & 8 & 0.27 & 0.01 & 0.22 \\
\hline Food and beverage and tobacco products & 14 & 0.47 & 0.10 & 1.15 \\
\hline Textile mills and textile product mills & 5 & 0.40 & 0 & 0 \\
\hline Apparel and leather and allied products & 6 & 0.17 & 0 & 0 \\
\hline Wood products & 12 & 0.59 & 0.08 & 0.26 \\
\hline Paper products & 11 & 0.14 & 0.10 & 0.78 \\
\hline Printing and related support activities & 4 & 0.25 & 0.02 & 0.36 \\
\hline Petroleum and coal products & 11 & 0.04 & 0.20 & 0.43 \\
\hline Chemical products & 14 & 0.43 & 0.17 & 2.38 \\
\hline Plastics and rubber products & 6 & 0.20 & 0.07 & 0.78 \\
\hline Nonmetallic mineral products & 13 & 0.53 & 0.32 & 0.83 \\
\hline Primary metals & 9 & 0.67 & 0.17 & 0.62 \\
\hline Fabricated metal products & 12 & 0.49 & 0.06 & 0.75 \\
\hline Machinery & 11 & 0.44 & 0.10 & 1.06 \\
\hline Computer and electronic products & 14 & 0.37 & 0.09 & 1.10 \\
\hline
\end{tabular}


Table 6 (Continued)

\begin{tabular}{|c|c|c|c|c|}
\hline \multirow[t]{2}{*}{ Sector name } & \multirow[t]{2}{*}{ Obs. } & \multicolumn{3}{|c|}{ Mean } \\
\hline & & $\begin{array}{l}\text { Foreign-Acquirer- } \\
\text { Presence }\end{array}$ & $\begin{array}{l}\text { Merger-Policy- } \\
\text { Risk }\end{array}$ & $\begin{array}{l}\text { Merger-Policy- } \\
\text { Uncertainty }\end{array}$ \\
\hline $\begin{array}{l}\text { Electrical equipment, appliances, and } \\
\text { components }\end{array}$ & 10 & 0.57 & 0.07 & 0.51 \\
\hline Transportation equipment manufacturing & 13 & 0.43 & 0.08 & 0.98 \\
\hline Furniture and related products & 4 & 0.37 & 0 & 0.22 \\
\hline Miscellaneous manufacturing & 14 & 0.26 & 0.06 & 0.92 \\
\hline Wholesale trade & 12 & 0.30 & 0.07 & 2.83 \\
\hline Air transportation & 10 & 0.06 & 0.33 & 0.77 \\
\hline Water transportation & 7 & 0.62 & 0.40 & 0.61 \\
\hline Truck transportation & 10 & 0.15 & 0.26 & 0.31 \\
\hline Pipeline transportation & 14 & 0.08 & 0.10 & 0.69 \\
\hline Other transportation and support activities & 7 & 0.59 & 0.20 & 0.26 \\
\hline $\begin{array}{l}\text { Publishing industries, except internet } \\
\text { (includes software) }\end{array}$ & 14 & 0.24 & 0.09 & 1.29 \\
\hline $\begin{array}{l}\text { Motion picture and sound recording } \\
\text { industries }\end{array}$ & 12 & 0.24 & 0.24 & 0.66 \\
\hline Broadcasting and telecommunications & 10 & 0.23 & 0.13 & 2.37 \\
\hline $\begin{array}{l}\text { Data processing, internet publishing, and } \\
\text { other information services }\end{array}$ & 14 & 0.11 & 0.15 & 1.22 \\
\hline $\begin{array}{l}\text { Federal Reserve banks, credit } \\
\text { intermediation, and related activities }\end{array}$ & 12 & 0 & 0.02 & 0.42 \\
\hline $\begin{array}{l}\text { Securities, commodity contracts, and } \\
\text { investments }\end{array}$ & 14 & 0.26 & 0.04 & 1.16 \\
\hline Insurance carriers and related activities & 13 & 0.25 & 0.04 & 0.75 \\
\hline Funds, trusts, and other financial vehicles & 6 & 0.001 & 0 & 0 \\
\hline Real estate & 9 & 0.24 & 0.11 & 0.15 \\
\hline $\begin{array}{l}\text { Rental and leasing services and lessors of } \\
\text { intangible assets }\end{array}$ & 13 & 0.35 & 0.07 & 0.65 \\
\hline $\begin{array}{l}\text { Professional, scientific, and technical } \\
\text { services }\end{array}$ & 14 & 0.36 & 0.06 & 1.53 \\
\hline Administrative and support services & 14 & 0.39 & 0.05 & 0.55 \\
\hline $\begin{array}{l}\text { Waste management and remediation } \\
\text { services }\end{array}$ & 9 & 0.20 & 0.30 & 0.86 \\
\hline Educational services & 8 & 0.18 & 0.01 & 0.22 \\
\hline Ambulatory health care services & 13 & 0.18 & 0.18 & 1.19 \\
\hline Hospitals & 13 & 0.02 & 0.07 & 1.25 \\
\hline Nursing and residential care facilities & 10 & 0 & 0 & 0 \\
\hline Social assistance & 4 & 0.43 & 0 & 0 \\
\hline $\begin{array}{l}\text { Performing arts, spectator sports, } \\
\text { museums, and related activities }\end{array}$ & 6 & 0.17 & 0.13 & 0.15 \\
\hline $\begin{array}{l}\text { Amusements, gambling, and recreation } \\
\text { industries }\end{array}$ & 9 & 0.18 & 0.07 & 0.60 \\
\hline Accommodation & 13 & 0.06 & 0.10 & 0.29 \\
\hline Food services and drinking places & 9 & 0.13 & 0 & 0 \\
\hline Other services, except government & 10 & 0.19 & 0.3 & 0.64 \\
\hline Total & 563 & 0.27 & 0.11 & 0.82 \\
\hline
\end{tabular}


Open Access This article is licensed under a Creative Commons Attribution 4.0 International License, which permits use, sharing, adaptation, distribution and reproduction in any medium or format, as long as you give appropriate credit to the original author(s) and the source, provide a link to the Creative Commons licence, and indicate if changes were made. The images or other third party material in this article are included in the article's Creative Commons licence, unless indicated otherwise in a credit line to the material. If material is not included in the article's Creative Commons licence and your intended use is not permitted by statutory regulation or exceeds the permitted use, you will need to obtain permission directly from the copyright holder. To view a copy of this licence, visit http://creativecommons.org/licenses/by/4.0/.

Accepted by Robert Grosse, GuestEditor, 5 May 2020. This article hasbeen with the authors for threerevisions.

Publisher's Note Springer Nature remains neutral with regard to jurisdictional claims in published maps and institutional affiliations. 